\title{
Medicinal Value of Three Agricultural Weed Species of the Asteraceae Family: A Review
}

\author{
Mithila Jayasundera', Singarayer Florentine ${ }^{2, *}$, Kushan U Tennakoon ${ }^{3}$, Bhagirath Singh Chauhan ${ }^{4}$
}

\section{Mithila Jayasundera', Singarayer \\ Florentine ${ }^{2, *}$, Kushan U \\ Tennakoon ${ }^{3}$, Bhagirath Singh \\ Chauhan ${ }^{4}$}

${ }^{1}$ Faculty of Science, RMIT University,

Bundoora West Campus, Bundoora, VIC

3083, AUSTRALIA.

${ }^{2}$ School of Science, Psychology and Sport,

Federation University Australia, Mt Helen

Campus, Ballarat, VIC 3353, AUSTRALIA.

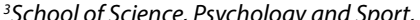

Federation University Australia, No.100 Clyde

Road, Berwick, VIC 3806, AUSTRALIA.

${ }^{4}$ Queensland Alliance for Agriculture

and Food Innovation, The University of

Queensland, Gatton, QLD 4343, AUSTRALIA.

\section{Correspondence}

\section{Singarayer Florentine}

School of Science, Psychology and Sport, Federation University Australia, Mt Helen Campus, Ballarat, VIC 3353, AUSTRALIA.

E-mail: s.florentine@federation.edu.au

\footnotetext{
History

- Submission Date: 16-09-2020;

- Review completed: 16-10-2020;

- Accepted Date: 26-10-2020
}

DOI : 10.5530/pj.2021.13.36

Article Available online

http://www.phcogj.com/v13/i1

\section{Copyright}

(C) 2021 Phcogj.Com. This is an openaccess article distributed under the term of the Creative Commons Attribution 4.0 International license.

\begin{abstract}
Ageratum conyzoides L., Tridax procumbens L. and Bidens pilosa L. are well known plant species of the Asteraceae family that are considered weeds in intensive agriculture. These weeds are traditionally known to have medicinal properties and have been used for therapeutic treatments. However, it is only the lack of proper knowledge, awareness and screening that have limited their use in pharmaceutical sectors. This review attempts to consolidate the traditional, phytochemical and pharmacological studies that have been carried out on Ageratum conyzoides L., Tridax procumbens L. and Bidens pilosa L., which we note are widely spread throughout the world. This study was conducted through a coherent search on Ageratum conyzoides L., Tridax procumbens $\mathrm{L}$. and Bidens pilosa $\mathrm{L}$. with respect to traditional uses, phytochemical and pharmacological studies that have been performed on these three agricultural weeds all over the world. An exploration of reported descriptions of the potential medical importance of three agricultural weed species ( $A$. conyzoides, T. procumbens and B. pilosa) has been presented. The present review would encourage further clinical investigations into these three plants and their extracts to more closely define the range of uses of these herbs for clinical applications. This, in turn, would give a clear understanding whether these weed species might be targeted to be conserved in a sustainable manner rather than eradicated.

Key Words: Ageratum conyzoides, Tridax procumbens, Bidens pilosa, Traditional use, Phytochemical, Pharmacological.
\end{abstract}

\section{INTRODUCTION}

Nature has been a prolific source of medicinal agents for a long period of time, and multifaceted progress has been achieved by researchers worldwide in utilization of medicinal plants for novel drug discoveries. ${ }^{1}$ However, over-utilization of known medicinal plants poses a serious threat to their survival, and it has become clear that substitutes for these resource plants has become increasingly urgent. Indeed, recently many strategies have been put forward to explore less utilized plants which are likely to be good sources of bioactive compounds. Weeds are one such group of plants, many of which are traditionally known to have medicinal properties.. ${ }^{2}$ Leaves, flowers (floral summits and flowering heads), aerial parts and fruits are the mostly used plant parts for medicinal purposes. 3-5. It is high time data is obtained from traditional repositories on the medicinal uses of weeds before this knowledge vanishes. The collection of such data from ephemeral sources serves bifold purpose: it not only supports the records of the intangible heritage of a country but can materially aid science in the search for new medically beneficial medicines or identifying other valuable outcomes from weeds. ${ }^{6}$ In this respect, it is reported that, four families of weeds (Asteraceae, Solanaceae, Lamiaceae and Papilionaceae) have high percentages of medicinally valuable weed varieties. Asteraceae shows the highest percentage $(18.6 \%)$ of useful family members followed by Solanaceae (9.3\%), Lamiaceae $(9.3 \%)$ and Papilionaceae $(6.6 \%) .{ }^{7}$ It is suspected that the high percentage of medicinal weed species in these families may reflect the presence of some important bioactive compounds. Bioactivity of components are attributed to the presence of a wide range of secondary active metabolites namely, flavonoids, terpenoids, alkaloids, steroids, and chromenes. ${ }^{8}$ This review tries to emphasize the accessible literature on three common agricultural weeds of the family Asteraceae namely, Ageratum conyzoides L., Tridax procumbens L. and Bidens pilosa L. It will focus on investigations related to traditional uses, identification of chemical constituents and summaries of various pharmacological activities. This review particularly aims to open new directions towards the increase of medicinal use of agricultural weeds for a wide range of illnesses and in doing so it would raise awareness of their innate value, thus adding importance to them as agricultural resources.

Therefore, this review will identify which agricultural weeds need conservation than total elimination under the tag "weeds". Such identification will also be beneficial in understanding on what species that need to be reconsidered for cultivation under controlled conditions, which will increase agrobiodiversity, sustainable utilization and accessibility of plant medicinal products

\section{AGERATUM CONYZOIDES L.}

\section{Background}

Ageratum conyzoides is a well-known herb (Figure 1) used for traditional medication purposes in many

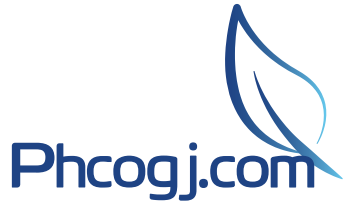

Cite this article: Jayasundera M, Florentine S, Tennakoon KU, Chauhan BS. Medicinal Value of Three Agricultural Weed Species of the Asteraceae Family: A Review. Pharmacog J. 2021;13(1): 264-77. 


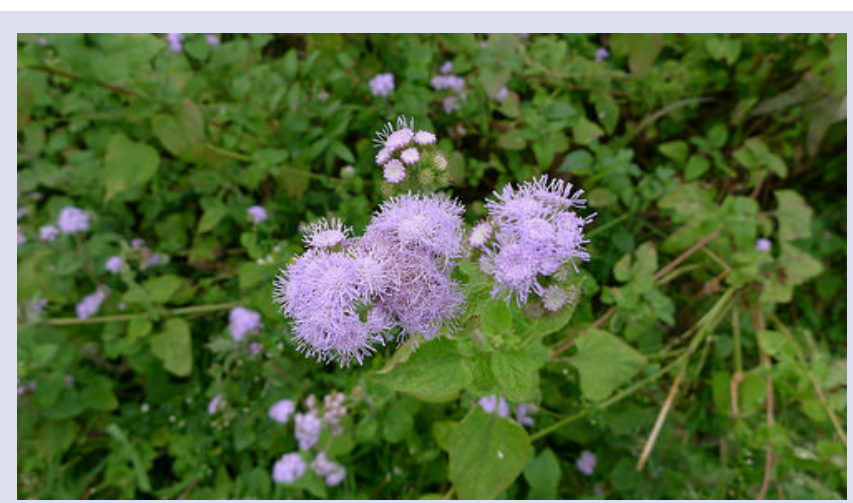

Figure 1: Ageratum conyzoides L.

Source: ALA (2020) Atlas of living Australia. http://www.ala.org.au Accessed 24/08/2020

https://images.ala.org.au/image/details?imageld=dabb0de9-f3074925-b89f-2da5e7602b03

countries for many years. ${ }^{9,10}$ The genus A. conyzoides is originated from the Greek words 'a geras' which points out to the long lifespan of the plant, and the species epithet 'konyz' is the name in Greek for Inula helenium. In Australia, this weed is more common in northern Queensland, and is often confused with blue billygoat weed (Ageratum houstonianum). Leaves of the seedlings are circular to egg shape, which are $3 \mathrm{~mm}$ in length and $3.5 \mathrm{~mm}$ in width. Early leaves are broadly eggshaped, with lightly serrated margins. The serrations are widely spaced, rounded and shallow. Later leaves have obvious serrated margins and clearly defined veins. Adult leaves are egg-shaped to triangular and are arranged in opposite pairs along the stems. Leaves are 10 to $100 \mathrm{~mm}$ in length and 10 to $60 \mathrm{~mm}$ in width and are borne on stems of 5 to 50 $\mathrm{mm}$ long. Leaves are mid-green and lightly hairy. A mature specimen is an erect annual or short-lived perennial plant which is 30 to 100 $\mathrm{cm}$ in height with hairy stems. Flowers are 4 to $5 \mathrm{~mm}$ in size and pale lavender blue to white in colour. They occur in fluffy clusters on the end of erect or slightly drooping stems. Seeds are 1 to $3 \mathrm{~mm}$ in length, black and topped by a fluffy pappus of five white hairs, which assist the seeds in wind dispersal. Apart from Northern Queensland, this weed is also found in New South Wales and the Northern Territory, being an introduced species from tropical America. ${ }^{11}$

\section{Traditional uses of Ageratum conyzoides $\mathrm{L}$}

Ageratum conyzoides is found in different locations in the world as a conventional medicine with records available from South America, Africa and Asia. ${ }^{10}$ The full plant induces a volatile strong-smelling oil which gives rise to a whole range of biological activities. ${ }^{10}$ The mature plant and the plant extract are used for its analgesic, antiinflammatory, antispasmodic, anti-asthmatic, antioxidant, antiurolithic, cardiovascular, depressant activities and insecticidal properties. ${ }^{10,12-16}$

The plant is used for headaches, dyspnoea, infectious and mental illnesses in some areas of Africa. ${ }^{9}$ This plant is applied for treating burn wounds in Central Africa, and in Kenya it is used for anti-asthmatic, antispasmodic and haemostatic treatment. ${ }^{10}$ It is used as an oil lotion for eye discharge and leprosy treatment in India. ${ }^{9}$ In Brazil, $A$. conyzoides leaves are used for analgesic, anti-inflammatory and antidiarrhoeic treatment. ${ }^{9,10}$ The plant is also used in Vietnam for treatment of gynaecological illnesses. ${ }^{10}$ The plant also has many reputed magical and supernatural features such as against snake bites. ${ }^{10}$ The leaf of the plant is supposed to have prospective hematopoietic features which could possibly cure anaemia ${ }^{10,17}$ and is further described to possess gastroprotective activity. ${ }^{10,18}$

\section{Chemical compounds found in Ageratum conyzoides $\mathrm{L}$}

\section{Monoterpenes and Sesquiterpenes}

Analysis of an A. conyzoides oil sample secured from Nigeria confirmed the presence of 51 constituents. This includes 20 monoterpenes (6.6\%) (of $1 \%$ is sabinene, $1.6 \%$ is $\beta$-pinene and $\beta$-phellandrene, $2.9 \%$ is 1.8 -cineole and limonene, $0.6 \%$ is terpenen- 4 -ol and $0.5 \%$ is a-terpineol) and a further 20 sesquiterpenes (5.1\%) were also found. $A$. conyzoides oil extracted from Indian plants contains $5.3 \%$ ocimene. This was found in minute amounts in the Nigerian plant in addition to $6.6 \%$ a-pinene, $4.4 \%$ eugenol and $1.8 \%$ methyl eugenol. ${ }^{8-10}$ Sesquiterpene, $\delta$ - cadinene, was about $4.3 \%$ in the oil extracted from Indian plants. ${ }^{8-10,19}$ Sesquiphellandrene (1.2\%) and caryophyllene epoxide (0.5\%) have been extracted from A. conyzoides leaves. ${ }^{8-10,20}$

\section{Flavonoids and Alkaloids}

Twenty- one polyoxygenated flavonoids were extracted from A. conyzoides species. They are the scutellarein-5,6,7,1tetrahydroxyflavone, quercetin, quercetin-3- rhamnopiranoside, kaempferol, eupalestin, quercetin-3- rhamnopiranoside, kaempferol 3,7- glucopyranoside and 14 different polymethoxy flavones. ${ }^{10,21}$ From the stems, another isoflavone glycoside, 5,7,2,19-tetrahydroxy-6,3-di-(3,3-dimethylallyl)- isoflavone- 5-O- $\alpha$ L-rhamnopyranosyl- $(1 \rightarrow 19)-\alpha$-L-rhamnopyranoside was extracted. ${ }^{8,10}$ Lycopsamine, echinatine, caffeic acid, phytol, 2-(2'-methylethyl) 5,6-dimethyoxybenzofuran,2-(2-methylprop-2- enyl)-2-methyl-6,7dimethoxychromane-4-one, 2-(1'-oxo- 2'methylpropyl)-2- methyl propyl)-2-methyl-6,7- dimethoxychromene and 3-(2'-methylpropyl)2-methyl-6,8-demothoxychrom-4-one are the alkaloids extracted from Ageratum species. ${ }^{8,22,23}$ Vitamins A and B are found in flowers [8]. Sesamin, fumaric acid, aurantiamide acetate, caffeic acid, phytol and hydrocarbons are the other extracted compounds. ${ }^{24}$

\section{Steroids and Triterpenes}

Major sterols such as friedeline, stigmasterol and beta-sitosterol and a minor sterol namely, brassicasterol have been distilled from the oil of leaves and stems of $A$. conyzoides. ${ }^{9}$ Six-weeks-old tissues of $A$. conyzoides had higher sterol contents, while in the case of in-vivo plant parts, slightly higher sterol contents were observed in the stem $(0.08 \%)$, followed by lower levels of the same in the leaves $(0.06 \%)$ and roots (0.05\%). 9,25

\section{Benzofuran, Chromene, Chromone and Coumarin}

Major compounds of essential oil of A. conyzoides are Precocene I or 7-methoxy-2,2- dimethyl chromene which ranges from $30 \%$ to $93 \%$, Precocene II which fluctuates from $0.7 \%$ to $55 \%$, cumarine $(5.01 \%)$ and $3.02 \%$ of trans caryophyllene. ${ }^{26-28}$ Essential oil also contains ageratochromene dimer, which suggests that the genus possesses chemotaxonomic activity. ${ }^{9,17}$ From the essential oil of aerial parts, seven chromene derivatives are extracted. They are the 2,2-dimethylchromene7-o- $\beta$ - glucopyranoside; 6-(1-methoxyethyl)-7-methoxy-2,2- dimethyl chromene; 6-(1-hydroxyethyl)-7-methoxy-2,2- dimethyl chromene; 6-(1-ethoxyethyl)-7-methoxy-2,2- dimethyl chromene; 6-angeloyloxy7-methoxy-2,2- dimethyl chromene, 3-(2-methylpropyl)-2-methyl6,8-demothoxychrom-4-one, 2-(2-methylethyl)-5,6- dimethyl benzofuran and a blend of ageratochromene dimer and encecanescin. It has also been found that coumarin (1.22\%), a small proportion of benzofuran and its derivatives were produced from essential oil of $A$. conyzoides isolated in Brazil., ${ }^{9,21}$ All the compounds which have been extracted from A. conyzoides are summarized in Table 1. 
Table 1: Compounds isolated from Ageratum conyzoides.

\begin{tabular}{|c|c|c|c|c|}
\hline Compound & Class & Source & Country & Reference \\
\hline Ageratochromene dimer & Chromene & Oil & India & 29 \\
\hline B-caryophyllene & Sesquiterpene & Oil & India & 20 \\
\hline Brassicasterol & Sterol & Oil & India & 30 \\
\hline Caffeic acid & Secondary metabolites & Oil & India & 21 \\
\hline Caryophyllene epoxide & Sesquiterpene & Oil & India & 20 \\
\hline Dihydrobrassicasterol & Sterol & Oil & India & 30 \\
\hline Echinatine & Alkaloids & Whole plant & Mexico & 23 \\
\hline Eugenol & Terpenes & Oil & India & 20 \\
\hline Fumaric acid & Secondary Metabolites & Oil & India & 21 \\
\hline Kaempferol-3,7- diglucopiranoside & Flavonoid & Oil & India & 21 \\
\hline Lycopsamine & Alkaloids & Oil & Mexico & 23 \\
\hline Methyleugenol & Terpenes & Oil & India & 20 \\
\hline Ocimene & Terpenes & Oil & India & 19 \\
\hline Precocene I (7-methoxy-2,2'-dimethyl chromene) & Chromene & Oil & Brazil & 28 \\
\hline Precocene II (ageratochromene) & Chromene & Oil & India & 27,31 \\
\hline Sesquiphellandrene & Sesquiterpene & Oil & India & 20 \\
\hline Spinasterol & Sterol & Oil & India & 30 \\
\hline Vitamins A and B & Vitamin & Flower & India & 32 \\
\hline a-pinene & Terpenes & Oil & India & 19 \\
\hline$\beta$-pinene & Terpenes & Oil & India & 20 \\
\hline$\delta$ - cadinene & Sesquiterpenes & Oil & India & 19 \\
\hline $\begin{array}{l}\text { 2-(1'-oxo-2'-methyl propyl)-2- methyl-6,7-dimethoxy } \\
\text { chromene }\end{array}$ & Chromene & Oil & India & 24 \\
\hline $\begin{array}{c}\text { 2-(2'-methyl prop-2'-enyl)-2-methyl-6,7-dimethoxy } \\
\text { chroman-19-one }\end{array}$ & Chromene & Oil & India & 24 \\
\hline 2-(2'-methyl propyl)-2-methyl-6,8-dimethoxychrom-19-one & Chromene & Oil & India & 24 \\
\hline 2-(2'-methyl ethyl)-5,6- dimethoxy benzofuran & Benzofuran & Oil & India & 24 \\
\hline $\begin{array}{c}5,7,2^{\prime}, 19^{\prime} \text { - tetrahydroxy- } 6,3^{\prime} \text {-di-(3,3-dimethylallyl)- isofla- } \\
\text { vone 5-o- } \alpha \text {-L-rhamnopyrosyl-( }(1 \rightarrow 19) \text { - } \alpha \text { L-rhamnopyrano- } \\
\text { side }\end{array}$ & Isoflavone & Stem & India & 33 \\
\hline Methyl-6,7-dimethoxy chromene & Chromene & Oil & India & 24 \\
\hline$(+)-$ sesamin & Alkaloids & Oil & - & 13 \\
\hline
\end{tabular}

Source:9

\section{Pharmacological effects of Ageratum conyzoides L}

\section{Anti-inflammatory effect}

Studies have shown that the leaves have been used on incisions and abrasions as an anti-inflammatory agent. ${ }^{34,35}$ The anti-inflammatory effect was tested in the carrageenan-induced anti-inflammatory paw edema model on Wistar Albino rats. ${ }^{36}$ These effects of $A$. conyzoides were confirmed by a study carried out on rats which led to a dramatic reduction $(p<0.05)$ in the growth of chronically induced paw edema and a notable scaling down of serum glutamic pyruvic transaminase (SGPT) activity to $30.2 \%(\mathrm{p}<0.05)$ in the rats treated with $500 \mathrm{mg} / \mathrm{kg}$ extract of $A$. conyzoides. ${ }^{35}$ In another study, a set of rats was subjected to $250 \mathrm{mg} / \mathrm{kg}$ hydro alcoholic extract orally and a $38.7 \%$ reduction in granuloma $(\mathrm{p}<0.05)$ was observed. ${ }^{37}$ Aqueous extract of a combination of A. conyzoides, Lippia multiflora and Cymbopogon citrates showed a dramatic drop in mouse writhings triggered off by acetic acid and a more intensified pain magnitude that must be exceeded in mice. The observed activities are supported by the presence of saponins and flavonoids, and this also suggests that in traditional preparations a combination of the above-mentioned plants could be used.$^{38}$ It was signified that water-soluble fractions (WSF) $(20$ to $50 \mathrm{mg} / \mathrm{kg}$ ) of hydro alcohol extract of $A$. conyzoides brought down the articular incapacitation induced by carrageenan in rats. ${ }^{35,39}$ It was also observed that the ethanolic root extract of A. conyzoides in a dose of 100 and $300 \mathrm{mg} / \mathrm{kg}$ led to a drastic drop in the carrageenan-influenced hind paw oedema in rats with no drastic virulent effect on mice. ${ }^{36,40}$ Another study was undertaken by Galati ${ }^{41}$ and his team to gauge the effect of flavonoid fraction and the methanol extract of the aerial part of the plant on carrageenan-triggered edema in rats. ${ }^{41}$ The two remedies provided a remarkable inhibition effect on carrageenan-induced rat paw edema, up to 2 hours after having been treated with carrageenan suggesting that the anti-inflammatory effect of $A$. conyzoides methanol extract relies on the flavonoid fraction. The flavonoid fraction promotes a defensive action against free radicals that cause impairment to cells and tissues. ${ }^{41}$

Mahmood and his team in 2005 investigated the cytoprotective activity of aqueous extracts of $A$. conyzoides leaves against ethanol-triggered gastric bruises in rats. ${ }^{42}$ It had been observed that the rats pre-treated with A. conyzoides extracts $(5 \mathrm{ml} / \mathrm{kg})$ at dosages of $250 \mathrm{mg} / \mathrm{kg}$ and $500 \mathrm{mg} / \mathrm{kg}$ separately before administering of absolute ethanol $5 \mathrm{ml} /$ $\mathrm{kg}$ orally revealed significantly higher suppression of gastric bruises and a reduction $(\mathrm{p}<0.05)$ of submucosal edema compared to those of the control group. ${ }^{42}$ Shirwaikar ${ }^{18}$ and his team discovered that the administration of an ethanol extract orally at dose levels of 500 and 750 $\mathrm{mg} / \mathrm{kg}$, significantly helped protect gastric bruises by 80.59 and $89.33 \%$, respectively in rats. ${ }^{18}$ The results strongly suggest that $A$. conyzoides extracts have favourable cytoprotective properties against ethanoltriggered gastric ulcers in rats. ${ }^{42}$

\section{Analgesic effect}

Analgesic effects have been explored in the acetic acid-influenced writhing model and the formalin-influenced licking model using Swiss 
Albino mice. In a dose-dependent response, A. conyzoides extracts suppressed $49.85 \%$ of acetic acid-influenced pain at the optimal dose of $2.0 \mathrm{~g} / \mathrm{kg}$. The effect was drastically significant $(\mathrm{p}<0.05)$ when compared to that of the reference drug, diclofenac sodium $(40 \mathrm{mg} / \mathrm{kg})$. A. conyzoides $(2.0 \mathrm{~g} / \mathrm{kg})$ reduced the formalin-induced pain by $35.48 \%$ which was also statistically significant $(\mathrm{p}<0.05)$ when compared to morphine $(0.5 \mathrm{mg} / \mathrm{kg})$. The results demonstrated the efficacious analgesic potential of $A$. conyzoides extracts, confirming their potential use in complementary and alternative therapies [36]. Aqueous extracts of $A$. conyzoides plant have shown an analgesic effect in $66 \%$ of patients and $24 \%$ of patients showed an enhancement in articulation mobility without any side effects [43]. Leaf extracts of $A$. conyzoides also showed analgesic activity. They reduced impetuous motor activity and led to a decrease in rectal temperature. ${ }^{34,43}$ It is worth reporting that the watersoluble fraction of $A$. conyzoides extract has peripheral analgesic action, which occurs in leucocyte-dependent inflammatory events. ${ }^{10,34,44,45}$

\section{Anticancer effect}

Cytotoxic activity of water, ethanol, butanol, petroleum ether and ethyl acetate of $A$. conyzoides were tested in-vitro on seven human and one mouse cancer cell lines namely, prostate carcinoma (DU-145), gastric carcinoma (SGC-7901), golima (U-251), non-small cell lung carcinoma (A-549), breast carcinoma (MDA-MB-231), hepatic carcinoma (BEL7402), colon adenocarcinoma (HT-29) and rat leukemia (P-388) using sulphorhodamine $\mathrm{B}$ assay. The highest cytotoxic activity was shown by ethylacetate extract on A-549, DU-145, SGC- 7901 and P-388 with half-maximal inhibitor concentration (IC50) levels of $0.68,9.97,14.88$ and $0.0003 \mu \mathrm{g} / \mathrm{ml}$, respectively. The results revealed that these extracts possess anticancer property. ${ }^{46}$

\section{Antimicrobial and wound healing properties}

The antimicrobial effects of an ethyl alcoholic extract of A. conyzoides on Pseudomonas aeruginosa, Staphylococcus aureus, Escherichia coli, and Shigella dysenteriae were evaluated by agar-well diffusion technique and both the minimum inhibitory concentration (MIC) and minimum bactericidal concentration (MBC) of the ethyl alcoholic extract were recorded. ${ }^{47}$ It was reported that all the test organisms were vulnerable to $\geq 50 \mathrm{mg} / \mathrm{ml}$ of the extract. The MIC and MBC of the ethyl alcoholic extract of the A. conyzoides against $S$. aureus and E. coli was $120 \mathrm{mg} / \mathrm{ml}$ and the values were $160 \mathrm{mg} / \mathrm{ml}$ and $200 \mathrm{mg} / \mathrm{ml}$ of extract for $P$. aeruginosa and $S$. dysenteriae, respectively. The results advocated that the ethyl alcoholic extracts of $A$. conyzoides are used for treating sicknesses caused by $S$. aureus, $P$. aeruginosa and E. coli and $S$. dysenteriae. ${ }^{47}$ In another study, Wistar rats $(\mathrm{n}=10)$ were used to study the wound relieving effect of a methanolic extract of $A$. conyzoides. Wounds were packed with gauze dipped in methanolic extracts and after 10 days the wounds were examined microscopically to the depth of cells and tissues. Methanolic extracts-treated areas showed a less number of inflammatory cells and more fibrosis than those of the controls. It was shown that sores packed with aqueous extract, honey and solcoseryl ointment accelerated the process of wound recovery significantly. ${ }^{10,48}$ The methanolic extract showed a very influential antibacterial activity against Helicobacter pylori, which is a key etiological agent in duodenal, peptic and gastric ulcers. ${ }^{49}$ The antimicrobial activity of methanolic extract was determined against both Gram-positive and Gram-negative bacteria namely, Escherichia coli, Staphylococcus aureus, Streptococcus pyogenes, Salmonella enetrica and Pseudomonas putida and it was found that the extract inhibited the growth of all bacteria under study. The diameter of the region of inhibition formed by A. conyzoides $(100 \mathrm{mg} /$ $\mathrm{ml}$ ) for E. coli, S. aureus, P. puitda, S. enterica and S. pyogenes were $14 \mathrm{~mm}, 18 \mathrm{~mm}, 13 \mathrm{~mm}, 12 \mathrm{~mm}$ and $10 \mathrm{~mm}$, respectively, indicating that the methanolic extract showed the highest antibacterial property against S. aureus, a Gram-positive bacterium. ${ }^{50}$ However, another study showed that methanolic extract had no inhibition for four strains of $S$. aureus, two strains of $E$. coli, one strain of $P$. aeruginosa, three strains of Proteus species and one strain of Shigella species. ${ }^{51}$ The essential oil has shown antimicrobial and anticonvulsant characters. ${ }^{10,52,53}$ The oil was shown to inhibit 20 bacteria and four fungi namely, Candida albicans SP-14, Cryptococcus neoformas SP- 16, S. rolfsii SP-5 and T. mentagrophytes SP-12. ${ }^{54}$ Furthermore, the oil has been found to be effective against Penicillium chrysogenum and Penicillium javanicum. ${ }^{20}$ The fungitoxicity of essential oils of $A$. conyzoides on the fungus Didymella bryoniae was tested in vitro by means of germination of spores and mycelial growth. Results revealed that mycelial growth and germination of the spores of $D$. bryoniae were completely suppressed by the essential oil of $A$. conyzoides. ${ }^{10,55}$ Essential oil also has acute toxicity against the fungi namely, Epidermophyton floccosum, Trichophyton mentagrophytes and Microsporum gypseum which cause ringworm with mycelial inhibition being $80.28 \%, 78.43 \%$ and $68.24 \%$, respectively. ${ }^{56} A$. conyzoides aqueous extract was screened against three Gram-positive bacteria and seven Gram-negative bacteria. The results revealed that the growth of Alcaligenes viscolactis, Klebsiella aerogenes, Bacillus cereus and Streptococcus pyogenes were significantly controlled by the aqueous extract. $^{10,57}$ The minimum inhibition concentration (MIC) and antimethicillin resistant staphylococcus aureus test (MRSA) for ethanol and water extracts were recorded as 30.6 to $193.0 \mu \mathrm{g} / \mathrm{kg}$ and 195.19 to 71.0 $\mu \mathrm{g} / \mathrm{kg}$, respectively. ${ }^{58}$ Wound healing properties were also determined by Almagboul and his team ${ }^{59}$ and according to them the percentile values were more than $90 \%$ and $72 \%$ for the extract and the distilled water-treated group, respectively. ${ }^{59}$

\section{Radioprotective effect}

A set of mice were exposed to gamma radiation (10 Gy) to check the mortality rate after treating them with ethanolic extract of $A$. conyzoides. ${ }^{43}$ The mortality rate of rats exposed to gamma radiations was most effective at a dose of $75 \mathrm{mg} / \mathrm{kg}$ alcoholic extract, which lessens severe signs of sickness caused by radiation and mortality at all the exposure doses of radiation. It is suggested that this thereby increases survival rate at all radiation doses, and it also protected mice against the effects of related lethal gastrointestinal and bone marrow depressions. The protection attributes of the $A$ conyzoides ethanolic extract against gamma radiation is due to the scavenging of free radicals of oxygen molecules. ${ }^{10,43}$

\section{Anticoccidial effect}

It was demonstrated that the essential oil extracted from this plant has significant efficacy in the treatment of caecal coccidiosis of broilers. ${ }^{60}$ Acute toxicity tests were carried out using 28-day-old broiler chicks which were divided into six groups of five birds each. The birds were subjected to $250-3000 \mathrm{mg}$ of extract/kg body weight orally. Each group was given equal volumes of distilled water, and observations were made to detect signs of toxicity. Acute toxicity test showed no sign of toxicity. The extract reduced the faecal oocyst output of the infected birds steadily until it dropped down to zero after 18 days of treatment. This was similar to the decrease caused by Amprolium, a standard anticoccidial medication. The results revealed that the extract could further be developed into a phytomedicine in treating coccidiosis. ${ }^{60}$

\section{Schistosomicidal effect}

Essential oil of $A$. conyzoides was studied for its schistosomicidal effect against adult worms of Schistosoma mansoni in vitro. A drop in the number of eggs of the mature worms in a dose-dependent manner was observed. Thus, the essential oil helps to develop new schistosemicidal agents. ${ }^{61}$

\section{Other properties}

The leaf extract is commonly utilized for pain relief in osteoarthritic patients, showing it has an analgesic effect and improvement in 
articulation mobility. The aqueous leaf extracts are also reported to act as anti-coagulants which significantly decrease bleeding time. ${ }^{62}$ Glutathione levels in the liver and in the lymphoma cells of tumourbearing rats were decreased by an aqueous extract of $A$. conyzoides root. ${ }^{63}$ The leaf extract had a positive consequence on the atrial impulse velocity and coronary vessel resistance in an isolated guinea pig heart ${ }^{64,65,66}$ The extracts of roots and aerial part inhibited uterine contractions of rats suggesting that the plant extract exhibits specific anti-serotonergic activity on the isolated uterus. ${ }^{66}$ Haemopoietic properties were exhibited by ethanolic leaf extracts of $A$. conyzoides ${ }^{67}$ A. conyzoides is also used in the treatment of abdominal and menstrual pains. ${ }^{21}$ Petroleum ether extracts of $A$. conyzoides with IC50 values 1925.60 and $267.90 \mathrm{ppm}$ were found to be effective against the larvae of the mosquito Culex quinquefasciatus. ${ }^{68}$

\section{TRIDAX PROCUMBENS L.}

\section{Background}

Tridax procumbens $\mathrm{L}$. is a typical medicinal herb (Figure 2) that belongs to family Asteraceae (Daisy family) which is used by native-medical practitioners. It is mostly called as 'tridax' or 'tridax daisy' and in English it is popularly known as 'coat buttons' due to the appearance of its flowers. ${ }^{1,69}$ It is an annual or perennial, semi prostate and creeper weed from Central America. Leaves are simple, opposite, exstipulate, lanceolate or ovate, coarsely toothed margins and hairy. Flowers are at the terminals of the long sometimes twisted stems, which are 25 to 40 $\mathrm{cm}$ in length. These stems may be reddish and heavily haired at the base but are green and hairless along most of their length. ${ }^{11}$ Flowers are tubular and yellow with hairs. Flowering occurs all year and it has bisexual flowers with basal placentation. ${ }^{70}$ The herb is tolerant to drought, heat and humidity, pollution, seashore, slope and wind [1]. T. procumbens is present through tropical and sub-tropical Australia. It is a background weed which is found most commonly in the Central Queensland cotton area but is also found as far down as Northern NSW. It grows in pastures, fallows, cultivation, on roadsides and in disturbed areas. ${ }^{11}$

\section{Traditional uses of Tridax procumbens $\mathrm{L}$}

The tridax plant is present all over India and is utilized as an indigenous medicine for a variety of ailments. ${ }^{71}$ It has been widely used in the

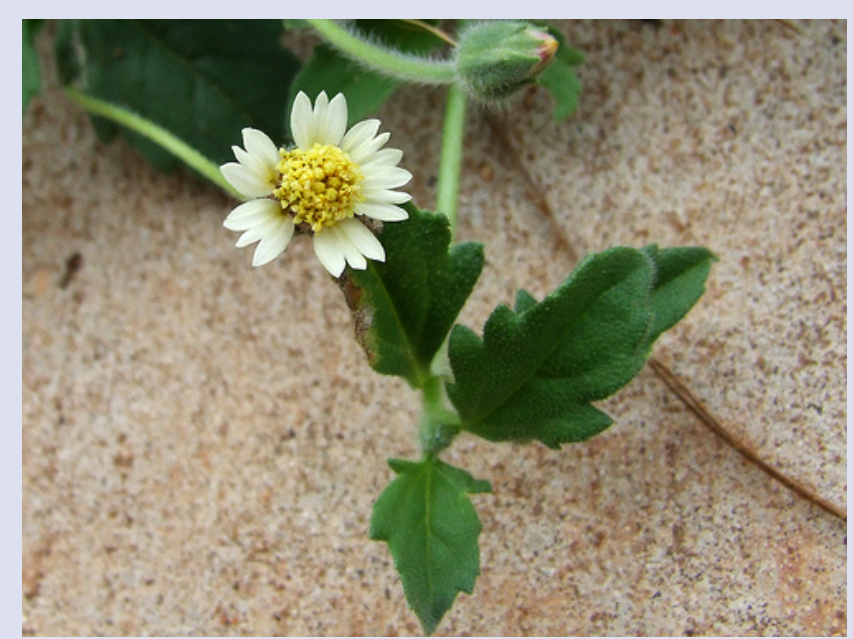

Figure 2: Tridax procumbens $L$.

Source: ALA (2020) Atlas of living Australia. http://www.ala.org.au Accessed 24/08/2020

https://images.ala.org.au/image/details?imageld=2e9dcd18-e8474be9-bc62-fd36897a196a
Ayurvedic medicine due to the presence of medicinal properties for reducing blood pressure, bronchial catarrh, malaria, dysentery, diarrhea, stomach-ache, wound healing and for headache. It also prevents hair loss and haemorrhage from cuts and bruises. ${ }^{71,72}$ Its flowers and leaves possess antiseptic, insecticidal and parasiticidal properties. ${ }^{69,71}$ The plant also shows various pharmacological activities such as immunomodulatory, antidiabetic, antihepatotoxic, antioxidant, anti-inflammatory, analgesic, anticancer and marked depressant action on respiration..$^{71,73-76}$

\section{Chemical constituents of Tridax procumbens $L$}

Phytochemical screening has shown the existence of flavonoids, alkaloids, carotenoids, $\beta$-sitisterol, n-hexane, fumaric acid, luteolin, glucoluteolin quercetin, isoquercetin, dexamethasone, oxoester, rutin, lauric acid, myristic, palmitic, arachidic, linoleic acid and tannin. ${ }^{1,77-80}$ A novel flavonoid named 'procumbenetin' has been extracted from the aerial parts of the plant and has been identified as 3,6- dimethoxy-5, 7, 2', 3', 4'- pentahydroxy flavone 7- $O$ - $\beta$-glucopyranosid. ${ }^{72}$ In addition, two novel flavones, $8,3^{\prime}$-dihydroxy-3,7,4'-trimethoxy-6-O- $\beta$-Dglucopyranosyl flavone and 6,8,3'-trihydroxy-3,7,4'-trimethoxyflavone were extracted from $T$. procumbens along with the four other wellknown constituents, puerarin, esculetin, oleanolic acid and betulinic acid. The data showed that $6,8,3^{\prime}$-trihydroxy-3,7,4'-trimethoxyflavone higher antioxidant activity compared to that of $8,3^{\prime}$-dihydroxy-3,7, $4^{\prime}$ trimethoxy-6-O- $\beta$-D-glucopyranosyl flavone. ${ }^{81}$ It was also found that $\quad 8,3^{\prime}$-dihydroxy-3,7,4'-trimethoxy-6-O- $\beta$-D-glucopyranosyl flavone having the same geometry of a triterpene fragment, which is practically the same as that of taraxasterol acetate. ${ }^{81}$ Bis-bithiophene and four other new terpenoids were obtained from $T$. procumbens namely, taraxasteryl acetate, beta-amyrenone, oleanolic acid and lupeol. ${ }^{82}$ The mineral composition of T. procumbens, obtained from analysis of its leaves, indicates that the plant is a rich source of calcium, magnesium, potassium, sodium and selenium. It has been observed that $T$. procumbens can be used as a prospective source of provitamin A (carotenoid) ${ }^{83,84}$ The leaves of T. procumbens contain $26 \%$ crude proteins, $17 \%$ crude fibre, $39 \%$ soluble carbohydrates and $5 \%$ calcium oxide. Oleanolic acid which is found in significant amounts in tridax has shown antidiabetic properties. ${ }^{85,86}$ Two water soluble polysaccharides, which contain the $\beta-(1->6)-D$ galactan main chain have also been extracted from the leaves of tridax..$^{1,87}$

\section{Pharmacological effects of Tridax procumbens $L$}

\section{Wound healing effect}

Leaf juice of $T$. procumbens not only promoted healing but also had the potential in overcoming steroid depressed healing in male Wistar rats. ${ }^{88-91}$ Both the aqueous extract and the whole plant were effective in increasing lysyl oxidase which is accountable for the wound healing effect. ${ }^{89}$

\section{Hepatoprotective effect}

Alcoholic extracts of aerial parts and chloroform soluble and insoluble fractions of T. procumbens were evaluated for hepatoprotective properties against d- Galactosamine/Lipopolysaccharide (D-GalN/LPS) triggered hepatitis in rats by a single dose of carbon tetrachloride. ${ }^{73,75,89,92}$ Acute and chronic models of hepatic damage were monitored by studying morphology, metabolic, histological and biochemical parameters. T. procumbens demonstrated antihepatotoxic action. Both ethanolic extract and chloroform insoluble fraction exhibited hepatoprotective effect. $^{73,89}$

\section{Hypotensive effect}

Hypotensive efficacy of an aqueous extract from the leaf of $T$. procumbens were explored on Sprague-Dawley rats who have been 
pre-anaesthetized. The intravenous administration of 3,6, and $9 \mathrm{mg} /$ $\mathrm{kg}$ of the aqueous extract caused a dramatic drop in the average arterial blood pressure in a dose-dependent sequence, leading to a substantial decrease in the average arterial blood pressure at higher dose than that at lower dose. ${ }^{93}$ Higher doses of the extract, $6 \mathrm{mg} / \mathrm{kg}$ and $9 \mathrm{mg} / \mathrm{kg}$ led to significant drop in the heart rate while lower dose of the extract $(3 \mathrm{mg} /$ $\mathrm{kg}$ ) did not lead to any significant change in the heart rate. ${ }^{93}$

\section{Immunomodulatory effect}

The immunomodulatory properties of aqueous extract (ethanol insoluble fraction) of $T$. procumbens have been explored. ${ }^{94,95}$ Upon intraperitoneal administration of the extract in doses of 0.25 and 0.5 $\mathrm{g} / \mathrm{kg}$ body weight (BW) significant increases in phagocytic index, leucocyte count and splenic antibody secreting cells were noticed. ${ }^{95}$ It was revealed that $T$. procumbens has an impact on both the humoral as well as the cell-mediated immune system. ${ }^{95}$

\section{Antidiabetic effect}

Leaf extracts of T. procumbens in water and ethanol showed a drastic drop in the blood glucose level in the alloxan-induced diabetes in rats [95]. In another study, leaf extracts of Tridax procumbens in water, alcohol and petroleum ether were subjected to hypoglycaemic activity in Wistar rats weighing between 150 and $200 \mathrm{~g}$. Leaf extracts which are orally administered at a dosage of $200 \mathrm{mg} / \mathrm{kg}$ led to a dramatic reduction in blood glucose. ${ }^{71}$

\section{Anticancer effect}

The effect of anticancer efficacy of crude water and acetone extracts of the flowers of $T$. procumbens was checked on prostate epithelial cancerous cells (PC3) by measuring the viability of these cells by an MTT [3-(4, 5-dimethyl -thiazole-2-yl)-2, 5-diphenyl tetrazolium bromide] assay. The acetone extract of flower led to an $82.3 \%$ death of cancer cells in 24 hours while the aqueous extract exhibited a very low anticancer efficacy. ${ }^{76}$

\section{Antimicrobial effect}

Water extracts have been tested for antibacterial functions against three Gram positive bacteria and seven Gram negative bacteria. The maximum suppression was observed by $T$. procumbens against Aeromonas hydrophilla and Bacillus cereus. ${ }^{96}$ In another study whole plant extract was tested on Bacillus subtilis, Staphylococus aureus, Escherichia coli and Pseudomonas aeruginosa. ${ }^{97}$ However, it was only against Pseudomonas aeruginosa that $T$. procumbens showed antibacterial activity. ${ }^{98}$

\section{BIDENS PILOSA L.}

\section{Background}

Bidens pilosa is a perennial plant with opposite leaves, white and yellow flowers and small black seeds (Figure 3). It grows to $1.0 \mathrm{~m}$ or more in height in favourable environments. ${ }^{99}$ Sunlight and dry soil are the ideal growth parameters. However, it can grow in any areas that are dry and infertile, waste ground or roadsides. This contributes to its distribution worldwide, and it also has a widely recognised use as a home remedy, thus $B$. pilosa warrants being a miraculous source of food and medicine. ${ }^{100,101}$ It is noted that there are 230 to 240 identified Bidens' species ${ }^{102}$ and because of its wide distribution, it is variously known as cobbler's pegs, beggar's tick, stick-fast, stick-tight and stickybeak. B. pilosa is thought to have evolved from temperate and tropical America ${ }^{103}$ and many studies have shown that there is a big demand worldwide for the use of this plant as a food and a source of medicine. ${ }^{102}$

\section{Traditional uses of Bidens pilosa $\mathrm{L}$.}

It is recorded that in folk medicine, the whole plant, the aerial parts (flowers, leaves, seeds and stems) and the roots of B. pilosa serve the

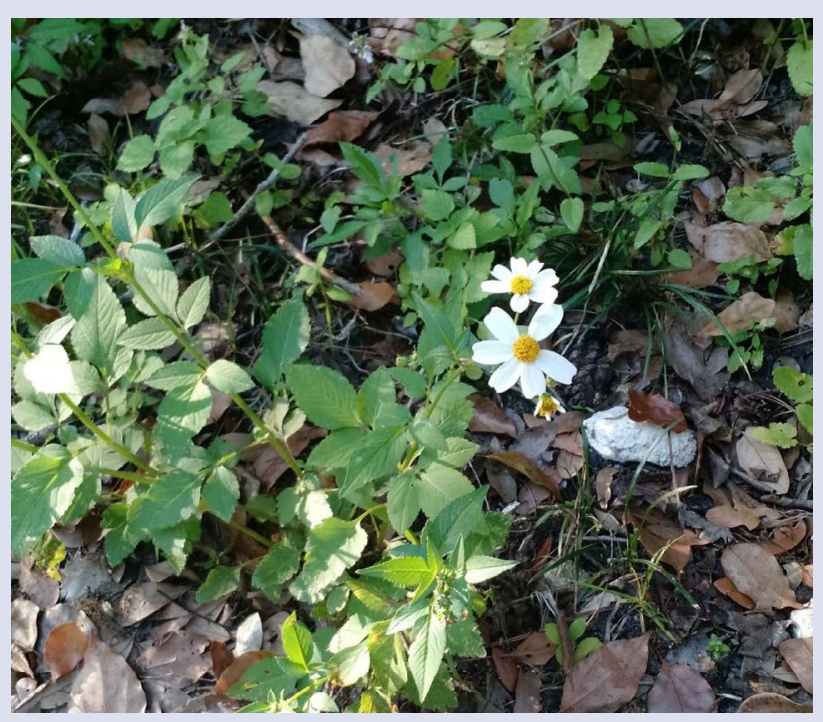

Figure 3: Bidens pilosa $L$.

Source: ALA (2020) Atlas of living Australia. http://www.ala.org.au Accessed 24/08/2020

https://images.ala.org.au/image/details?imageld=17206753-78564269-81e4-e47492c53ba5

purpose of treating more than 40 illnesses namely, inflammation, immunological disorders, digestive disorders, infectious ailments, wounds, cancers, metabolic syndrome. ${ }^{102,104-107}$ In this context, Bidens pilosa L. is usually prepared as a dry powder, maceration, decoction, or tincture ${ }^{108}$ and is usually taken orally. It is also used to good effect externally. For example, it has been noted that fresh B. pilosa is used in treating wounds and snake bites. ${ }^{102}$

\section{Chemical constituents of Bidens pilosa $\mathrm{L}$.}

B. pilosa is an incredible source of phytochemicals ${ }^{109,110}$ which include 301 compounds that fall into the following major chemical classes: polyacetylenes ${ }^{111}$, flavonoids ${ }^{112}$, phenolic acids, terpenes (monoterpenes, sesquiterpenes, diterpenes and triterpenes) pheophytins, fatty acids, phytosterols ${ }^{113,114}$ and some essential oils which are considered as the main active constituents responsible for the various pharmacological actions of the plant. ${ }^{102,115-118}$

\section{Polyacetylenes}

Thirty-seven polyacetylenic compounds are found in different parts of $B$. pilosa and their structural patterns show distinctive differences. Majority of the polyacetylenes discovered from this plant are aliphatic acetylenes containing triple and double bonds, in addition to cyclic, aromatic and glucoside rings or heterocyclic end groups. ${ }^{119}$

\section{Flavonoids}

Flavonoids and their derivatives, namely aglycones, aglycosides, aurones, and okanin glycosides, are found in most parts of $B$. pilosa. Twenty flavonoid glycosides have been extracted from $B$. pilos $a$ and out of which 10 compounds are available in the leaves. ${ }^{120,121}$

\section{Phenolics}

Thirty-three compounds of phenols have been found in various parts of B. Pilosa. ${ }^{118}$ Twelve caffeoylquinic acids and derivatives of p-coumaric acid, have also been isolated from the whole $B$. pilosa plant. Sashida and colleagues ${ }^{120}$ reported the presence of five derivatives of caffeoylquinic acid and two derivatives of p-coumaric acid in the leaves. Other caffeoylquinic acids have been found in the whole plant. ${ }^{16,121}$ 
There are 99 terpene compounds (monoterpenes, sesquiterpenes, diterpenes, triterpenes, and tetraterpenes) that have been isolated from B. pilosa. Among them there are 28 monoterpenes, 58 sesquiterpenes, six diterpenes and six triterpenes, while the others represent different types of terpenoid derivatives. They have been shown to contain both hydrocarbons and oxygenated compounds. Sesquiterpenes are mostly either monocyclic or bicyclic or tricyclic except for the two compounds namely, elixene and caryophyllene oxide which are linear sesquiterpenes ${ }^{118,119}$ and it is noted that the individual structures of sesquiterpenes show substantial differences. Majority of compounds of the monoterpenes and sesquiterpenes, are found in the essential oils obtained from various parts of $B$. pilosa. The acyclic diterpenes of compounds, spathulenol, pimaradiene and phytol were obtained from the whole B. pilosa plant. Two tricylic diterpenenes, namely, precocene 1 and phytyl heptanoate have been constituents of the essential oil derived from the shoots ${ }^{117}$, while the only relevant compound found in the leaf was a tetraterpene (Lupeol acetate). ${ }^{119}$

\section{Pheophytins, phytosterols and fatty acids}

Eight pheophytins have been extracted from the leaves of B. Pilosa. ${ }^{122}$ Two other pheophytins, decanal and tridecane containing two rare four- membered peroxides, have also been isolated. Six phytosterols and phytosterol derivatives analogous to the compounds campestrol, daucosterol, stigmasterol, $\beta$-sitosterol, $5 \alpha$-stigmasta-7-en-3- $\beta$-ol and $5 \alpha$-stigmasta-7,2-2t-dien-3 $\beta$-ol have been extracted from the whole plant. ${ }^{113}$ Other compounds, including derivatives of alkanes, alkaloids, acetylacetone, dicarbon;xylic acids, glycol ethers, tocopherols and thiophenes, have been found in the whole plant. ${ }^{119}$ Twelve long-chain fatty acids (behenic acid, 2-butoxyethyl linoleate, ethyl linoleate acid, methyl linolenate, linolenic acid, capric acid, elaidic acid, myristic acid, lauric acid, linoleic acid, palmitic acid, palmitoleic acid) are present in B. pilosa. Some of these fatty acids, such as linolenic acid, capric acid, elaidic acid, myristic acid and lauric acid have been discovered from the leaf essential oil. ${ }^{113,119}$

\section{Pharmacological uses of Bidens pilosa $\mathrm{L}$.}

\section{Anticancer effect}

Non-scientific writeups have divulged the prospective antitumor efficacy of $B$. pilosa and many scientific studies have underpinned the affirmation that $B$. pilosa extracts exhibit anticancer activities against different cancer cells. ${ }^{102,122-126}$ Kviecinski and co-workers tested the effect of hydro-alcoholic crude extracts, chloroform, methanol and ethyl acetate fractions on antitumor effect. The cytotoxicity of the extracts was tested with the use of haemolytic, brine shrimp and neutral red uptake (NRU) assays. In vivo studies in isogenic mice confirmed that the chloroform fraction was the most harmful and that it had a half maximal inhibitory concentration (IC50) of $97 \pm 7.2$ and $83 \pm 5.2 \mu \mathrm{g} / \mathrm{ml}$ in NRU and MTT, respectively. ${ }^{127}$ It was recorded that cancer is prevented by the phytochemical, luteolin at concentration levels of $5 \mu \mathrm{M}$ and $40 \mu \mathrm{M}$ for a significant amount of inhibition and complete inhibition, respectively, by inhibiting of cell adherence and invasion. ${ }^{122,123}$ Butein exhibited a toxic effect on colon adenocarcinoma cell proliferation of humans with an IC50 value of $1.75 \mu \mathrm{M} .{ }^{123}$ Anticancer activity in B lymphoma cells was also shown by centaureidin, favones and polyynes which are found in B. Pilosa. ${ }^{125}$ Two polyyne aglycones (1,2-dihydroxytrideca5,7,9,11-tetrayne and 1,3-dihydroxy-6(E)-tetradecene-8,10,12-triyne) were extracted from the ethyl acetate fraction of $B$. Pilos $a^{126}$ and the two compounds displayed anti-cell multiplication task in primary human umbilical vein endothelium cells (HUVEC) significantly. ${ }^{126}$

\section{Anti-inflammatory effect}

B. pilosa serves the purpose of treating inflammatory complications. ${ }^{128,129}$ Cyclooxygenase-2 (COX-2) converts arachidonic acid to prostaglandin
(PGE2) which is triggered by several external factors. This in return indicates its linkage to inflammatory diseases. ${ }^{128}$ The effects of the aqueous extracts of the aerial parts of $B$. pilosa on the production of COX-2, PGE2 and on the activation of mitogen-activated protein kinases (MAPKs) with respect to inflammatory cytokine, IL- $1 \beta$ were studied by Yoshida and his team in 2006. ${ }^{128}$ It was interesting to note that IL- $1 \beta$ activated MAPKs and thereby induced COX-2 expression. This study shows that the extracts of B. Pilosa can be used as antiinflammatory agents. In a study carried out by Horiuchi and Seyama in 2008 , the dried powder of the aerial part of B. pilosa, which had been pretreated with the enzyme cellulosine, was used in mice to check for antiinflammatory activity. ${ }^{129}$ It was noted that oral administration of B. pilosa treated with cellulosine lowered the level of serum immunoglobulin $\mathrm{E}$ (IgE) in mice upon immunization with 2,4-dintrophenyl (2,4-DNP)Ascaris as an antigen after 10 days. Furthermore, addition of cellulosine elevated the percentage of caffeic acid and flavonoids which indicates that B. pilosa and its related phenolics (luteolin and ethyl caffeate) have anti-inflammatory functions. ${ }^{129}$

\section{Antidiabetic effect}

Bidens pilosa serves as an anti-diabetic herb in Asia, Africa, and America ${ }^{130,131}$ and reports indicate that it is popularly cast off in patients suffering from diabetes mellitus worldwide. ${ }^{66,111,112,132-137}$ The extract of dried B. pilosa boiled with $15 \%$ water/ethanol for $5 \mathrm{~min}$, results in significant hypoglycaemic efficacy in normoglycemic mice and in mildly diabetic mice influenced by alloxan with fasting glycemia (200$340 \mathrm{mg} / \mathrm{dl}$ ). However, B pilosa did not have any efficacy on severely diabetic mice. This suggests that insulin is required as a mediator of the hypoglycaemic effect of the plant extracts. Studies carried out so far, have revealed that $B$. pilosa could be used in treating type 1 diabetes (T1D) and type 2 diabetes (T2D) in animals. Cytopiloyne, which is a polyyne found in $B$. pilosa had the most effective anti-T1D efficacy. ${ }^{135}$ The researchers further studied the anti-diabetic properties of three B. pilosa varieties, B. pilosa L. var. radiate (BPR), B. pilosa L. var. pilosa (BPP) and B. pilosa L. var. minor $(\mathrm{BPM})$ in mice $(\mathrm{db} / \mathrm{db}){ }^{111}$ Postprandial blood glucose levels in $\mathrm{db} / \mathrm{db}$ mice were decreased by oral administration $(10,50$ and $250 \mathrm{mg} / \mathrm{kg}$ body weight) of BPR, BPP, or BPM crude extracts for up to four hours. The BPR extract out of the three species led to a greater reduction in blood glucose levels than those of the other two species. ${ }^{111}$

\section{Antioxidant effect}

Antioxidant characteristics of B. pilosa and its fractions and compounds are determined by the measurement of free radical scavenging activity which was exhibited by the crude extract, ethyl acetate, butanol and water fractions of $B$. Pilosa. ${ }^{116,118,138}$ The compounds heptyl-2-O- $\beta$ ylofuranosyl-(1-6)- $\beta$-glucopyranoside, 3 - $O$-rabinobioside, quercetin 3-O-rutinoside, chlorogenic acid, 3,4- di-O-caffeoylquinic acid, 3,5-di-O-caffeoylquinic acid, 4,5-di-O-caffeoylquinic acid, jacein and centaurein all showed free radical scavenging properties [116]. It is interesting to note that the butanol and ethyl acetate fractions are more diligent than the crude extract and the water fraction of $B$. pilosa [116]. Only phenolic compounds out of the secondary metabolites such as 3 -[[6-O-(6-Deoxy- $\alpha$ - $L$-mannopyranosyl)- $\beta$ - $D$-galactopyranosyl] oxy]-2-(3,4-dihydroxyphenyl)-5,7-dihydroxy-4H-1-benzopyran4-one, quercetin 3-O-rutinoside, 3-[[3-(3,4-dihydroxyphenyl)-1oxo-2-propen-1-yl]-oxy]-1,4,5-trihydroxy-cyclohexanecarboxylic acid, 3,4-bis[[2(E)-3-(3,4-dihydroxyphenyl)-1-oxo-2-propen1-yl]-oxy]-1,5-dihydroxy-cyclohexanecarboxylic acid, and 3,4-bis[[(2E)-3-(3,4-dihydroxyphenyl)-1-oxo-2-propen-1-yl]oxo]1,5-dihydroxycyclohexanecarboxylic acid showed vigorous free radical scavenging properties. Most of the antioxidant compounds contain phenol moieties in their structure which could be attributed to the reducing/oxidation properties of phenols which help them 
to act as singlet oxygen quenchers, reducing agents and hydrogen donors. Therefore, many researchers have taken interest in analysing and quantifying methanol extract of $B$. pilosa for antioxidant activity, phenolic content and the phenolic profile and the phenol content was reported as $1102.8 \pm 2.2 \mathrm{mg} / \mathrm{g} .{ }^{102,138}$ Essential oils and monoterpenes of $B$. pilosa flowers and leaves have antioxidant properties with the leaves possessing the maximum activity. ${ }^{118}$ On the whole, phenolics and essential oils found in B. pilosa are considered to be antioxidant compounds of utmost importance.

\section{Immunomodulatory effect}

B. pilosa is believed to be an immunomodulatory herb and is noted to be efficacious in the treatment of allergies, arthritis and diabetes (T1D). ${ }^{112,129,135}$ Vulnerability to illnesses caused by viruses and bacteria are a result of defects in either IFN- $\gamma$ expression or regulation or activation. ${ }^{112}$ Interferon gamma (IFN- $\gamma$ ) is a major cytokine that intervenes with immune cells and retains pathogenic immunity. It was reported by Chang and colleagues that crude hot water extracts of $B$. pilosa increased IFN- $\gamma$ promoter activity bifold. ${ }^{112}$ Centaurein and centaureidin which were extracted from the butanol fraction led to a dramatic increase in IFN- $\gamma$ promoter activity. It was also reported that differentiation of type 1 helper $\mathrm{T}$ (Th1) cells and production of Th1 cytokines were suppressed by polyynes of $B$. pilosa. This result explains the anti-inflammatory and immunomodulatory effects of $B$. Pilosa. ${ }^{112,135}$

Immune cells of mice were influenced by phytochemical constituents of B. pilosa as it is believed that a lot of compounds show antagonistic or agonistic efficacies on immune response. Therefore, immune function of B. pilosa may rely on its composition and on some of the compounds, which could interpret better for the conflicting report on butanol extract of $B$. pilosa exasperating allergy in mice. However, cellulosinetreated extract ameliorated allergy. ${ }^{129,139}$

\section{Antimalarial effect}

Among the Asteraceae species, B. pilosa is one of the most effective and encouraging anti-malarial plants, as it shows powerful suppression towards parasitemia in in-vitro cultures. ${ }^{123,132,140-145}$ Dried whole plant materials of B. pilosa extracted with ethanol, butanol, and chloroform showed a $90 \%$ suppression towards the in vitro growth of the deadly malarial strain Plasmodium falciparum at $50 \mu \mathrm{g} / \mathrm{ml} .{ }^{140}$ The alcoholic extract of the root depicts a much higher suppression in mice infected with Plasmodium berghei than the whole plant, leaf and stem extracts. ${ }^{141}$ The chloroform fractions of the root apply an $86 \%$ suppression of Plasmodium falciparum growth in vitro. This outcome was confirmed in vivo, with a dramatic drop in parasitemia of up to $60 \%$ in mice infested with Plasmodium berghei at $250-500 \mathrm{mg} / \mathrm{kg} .{ }^{141}$ Plasmodium falciparum strains are vulnerable to B. pilosa at an IC50 value of $10.4-49.8 \mu \mathrm{g} /$ $\mathrm{ml}$ in vitro. Plasmodium falciparum (NF54 strain) in human blood is significantly suppressed at IC50 $=32.8 \mu \mathrm{g} / \mathrm{ml}$ using the hexane extract of $B$. pilosa leaves in in vivo assays. ${ }^{123}$ The chloroform, ether and ether methanol (1:1) fractions obtained from the root extract have given rise to a polyacetylenic compound namely, 1-phenyl-1,3-diyn-5-en-7-olacetate ${ }^{140,142}$ and two methoxylated flavonoids namely, centaureidin and digitoflavone (Luteolin) ${ }^{146}$. These show strong anti-malarial efficacies in vivo $^{141,142}$ and are bioactive towards Plasmodium. ${ }^{142}$

The strong anti-malarial efficacy of $B$. pilosa is likely due to its plentiful formation of polyacetylenes and flavonoids. For example, phenylheptatriyne (1-phenylhepta-1,3,5-triyne) is one of the major polyacetylenic compounds which is bioactive towards several malarial strains $^{143}$ and shows dominant suppression activity against Plasmodium falciparum, with IC50 $=6.1 \mu \mathrm{g} / \mathrm{ml} .{ }^{123}$ Another polyacetylenic compound also shows complete in vitro inhibition of Plasmodium falciparum at 1 $\mu \mathrm{g} / \mathrm{ml}$ and causes dramatic reduction of the Plasmodium berghei strain at $0.8 \mathrm{mg} / \mathrm{kg}$ in infected mice over four days. ${ }^{144}$ Campestrol is found in all parts of $B$. pilosa and is very effective in mice infested by Plasmodium berghei at a dose of $15 \mathrm{mg} / \mathrm{kg}$, suppressing parasitemia by up to $58 \%$ at eight days after parasite inoculation. ${ }^{145}$ It has also been observed that $B$. pilosa has prospective favourable therapeutic effects that can be used in the management of malaria. ${ }^{145}$

\section{Antibacterial effect}

Antibacterial efficacy of the essential oils extracted from the leaves and flowers of $B$. pilosa was determined in a study carried out by Deba and his team. ${ }^{118}$ Leaf and flower extracts and essential oils of B. pilosa showed varying extents of antibacterial efficacy. Essential oils showed much larger antibacterial efficacy compared to that of crude extracts in general. Greater antibacterial activity in essential oils could be due to the destroying of cellular integrity and inhibiting of the respiration and ion transport activities by the monoterpenes in the essential oils. As reported elsewhere, another reason could be attributed to the presence of anti-bacterial $\beta$-caryophyllene. ${ }^{118}$ Centaurein which is extracted from $B$. pilosa showed direct bacteriostatic and bactericidal activity ${ }^{112}$ by intensifying bactericidal activity in macrophages through intensified expression of IFN- $\gamma$ (interferon gamma). ${ }^{109,116}$ Centaurein was also found to overcome and cure Listeria infection via IFN- $\gamma$ expression in wild-type mice but not IFN- $\gamma$ knockout mice. ${ }^{147}$

\section{Antifungal effect}

Antifungal efficacy of hot water extracts of B. pilosa leaves, stems and roots against Fusarium solani, Corticium rolfsii and Fusarium oxysporum was evaluated. ${ }^{117}$ They observed that $C$. rolfsii was mostly controlled by the treatment with $B$. pilosa since its growth showed a dramatic drop for all the tested doses followed by F. oxysporum and $F$. solani. Stems and roots showed greater fungicidal activities than those of the leaves. ${ }^{117}$ Furthermore, the same group in 2008, determined the antifungal activity of both the aqueous extracts of leaves and flowers and the essential oils of B. Pilosa. ${ }^{117}$ They noted that the extracts and essential oils show antifungal activity against F. solani, $C$. rolfsii and $F$. oxysporum. However, essential oils showed higher fungicidal activity than that of water extracts. It is also worth noting that methanol, acetone and water extracts of the B. pilosa roots possess antifungal activities against Aspergillus flavus, Aspergillus niger and Penicillium notatum. ${ }^{148}$ The methanol extract of the $B$. pilosa roots at $10 \mathrm{mg} / \mathrm{ml}$ was also efficacious against Candida albicans. ${ }^{148}$

\section{Hypotensive effect}

Dimo and his team ${ }^{106}$ carried out their research in a hypertensive rat model to check the antihypertensive effect of aqueous and methylene chloride extracts of $B$. pilosa leaves. Ten percent fructose solution was given to the male Wistar rats ad libitum for three weeks followed by treating them with aqueous $(150-350 \mathrm{mg} / \mathrm{kg}$ ) and methyl chloride (150$300 \mathrm{mg} / \mathrm{kg}$ ) extracts of $B$. pilosa for another three weeks. Results showed that both the extracts of $B$. pilos $a$ leaves have a hypotensive activity on rats. ${ }^{106}$ The same authors carried out a study on neutralized extract of $B$. pilosa (NBP) and a mixture of methanol and methylene chloride in the ratio of 1: 1 . They investigated the heart rate and the blood pressure of mice after treating the mice with the above-mentioned formulation. ${ }^{149}$ A biphasic reduction in systolic blood pressure was observed with intravenous injection of NBP. On the other hand, an intravenous dose of the extract at 10,20 , and $30 \mathrm{mg} / \mathrm{kg} \mathrm{BW}$ decreased systolic blood pressure in normal rats by $18.3 \%, 42.5 \%$, and $30 \%$, respectively, whilst the same doses decreased the blood pressure in hypertensive rats by $25.8 \%, 38.9 \%$, and $28.6 \%$, respectively. ${ }^{149}$

\section{Wound healing effect}

Ethanolic extracts of Bidens pilosa and Ocimum suave were analysed for wound healing efficacy of rats by assessing a total of nine $(n=9)$ rats per group. ${ }^{150}$ The four groups of rats were subjected topically to either 
O. suave or B. pilosa or neomycin sulphate or distilled water twice a day. During the experimental period, the rate of wound contraction, epithelialization and complete healing were determined. Wounds subjected to extracts of $O$. suave or B. pilosa or neomycin sulphate showed greater rates of wound contraction compared to that of the control which is distilled water. Therefore, in the treatment of wounds, extracts of both $O$. suave and B. pilosa can be used as substitutes for neomycin. ${ }^{150}$

In another study, the Wistar rats were fed with $1 \mathrm{ml}$ of $\mathrm{HCl} /$ ethanol gastric necrotizing solution (150 $\mathrm{mM} \mathrm{HCl}$ in $60 \%$ ethanol) and eventually the effect of cyclohexane, methanol and methyl chloride extracts of $B$. pilosa on gastric ulcers in rats was examined. ${ }^{105}$ Methylene chloride extracts displayed the highest efficacy compared to those of the other two extracts on inhibition of lesions which is $46.4 \%$ inhibition at a dose of $500 \mathrm{mg} / \mathrm{kg} \mathrm{BW}$ and complete inhibition at $750 \mathrm{mg} / \mathrm{kg}$. The lowest efficacy against gastric ulcers in rats was shown by cyclohexane extracts with $13.3 \%, 40 \%$, and $79.7 \%$ inhibition at 500, 750 and 1000 $\mathrm{mg} / \mathrm{kg}$ BW, respectively. On the whole, the results propose that $B$. pilosa can be used to protect against $\mathrm{HCl} /$ ethanol-mediated ulcers. ${ }^{102}$

\section{CONCLUSION}

In this review, an exploration of reported descriptions of the potential medical importance of three agricultural weed species (A. conyzoides, T. procumbens and B. pilosa) has been presented. All these species have been claimed to exhibit pharmacological activities such as hepatoprotective activity, wound healing property, anti-inflammatory activity, hypotensive property, immunomodulating characteristic and antidiabetic effect.

These three species, Ageratum conyzoides, T. procumbens and $B$. pilosa were specifically chosen for attention because they are plants with traditional importance and have been used for generations as folk remedies. Indeed, as the review has indicated, many studies have corroborated the use of these plants as medicines which are efficacious with respect to several types of infections and a range of other medical conditions. Nevertheless, although the pharmacological features of these species have been evaluated, the mechanisms by which they work is yet to be established and the intent of this review is to encourage further investigations of these potentially valuable species.

Finally, since there is sufficient evidence as indicated by this review, it would encourage further clinical investigations into these three plants and their extracts in an attempt to more closely define the range of uses of these herbs for clinical applications. This, in turn, would give a clear understanding whether these weed species might be targeted to be conserved rather than eradicated.

\section{ACKNOWLEDGEMENTS}

This research was partly funded by the Research Support Program (2020) allocation of the Federation University School of Science, Psychology and Sport.

\section{CONFLICTS OF INTEREST}

The authors declare that they have no conflicts of interest to disclose.

\section{REFERENCES}

1. Ankita J, Jain A. Tridax procumbens (L.): A weed with immense medicinal importance: A Review. Int. J. Pharma Bio Sci. 2012; 3(1): 544-552.

2. Saroop S, Kaul V. Preliminary phytochemical analysis of Cleome viscosa - A Lesser explored crop of economic importance. Int. J. Pharma Bio Sci. 2015; 6(1):71-76

3. Akerreta S, Cavero RY, Calvo MI. First comprehensive contribution to medical ethnobotany of Western Pyrenees Silvia. J. Ethnobiol Ethnomed. 2007:3: 2639.
4. Bonet MÀ, Parada M, Selga A, Vallès J. Studies on pharmaceutical ethnobotany in the regions of L'Alt Empordá and Les Guilleries (Catalonia, Iberian Peninsula). J. Ethnopharmacol. 1999; 68 (1-3): 145-168.

5. Michel J, Rani NZA, Husain K. A Review on the Potential Use of Medicinal Plants from Asteraceae and Lamiaceae Plant Family in Cardiovascular Diseases. Frontiers in Pharmacology. 2020; 11: Article 852

6. Bonet MÀ, Vallès J. Pharmaceutical ethnobotany in the Montseny biosphere reserve (Catalonia, Iberian Peninsula). General results and new or rarely reported medicinal plants. J. Pharm Pharmacol. 2003; 55:259-270.

7. Njoroge NG, Bussmann WR, Gemmill B, Newton LE, Ngumi WW. Utilisation of weed species as sources of traditional medicines in central Kenya. Lyonia. 2004; 7(2):71-87.

8. Chauhan A, Rijhwani SA. Comprehensive Review on Phytochemistry of Ageratum conyzoides linn. (Goat weed). Int. J. Eng. Technol. Manag. Appl. Sci. 2015; 3: 348-358.

9. Okunade AL. Review: Ageratum conyzoides L. (Asteraceae). Fitoterapia. 2002 73: 1-16.

10. Singh SB, Devi WR, Marina A, Devi WI, Swapana N, Singh CB. Review: Ethnobotany, phytochemistry and pharmacology of Ageratum conyzoides Linn (Asteraceae). J. Med. Plant Res. 2013; 7(8): 371-385.

11. Richardson FJ, Richardson RG, Shepherd RCH. Weeds of the South-East: an identification guide for Australia. Meredith, Victoria: R. G. and F.R. Richardson (2nd edition), p. 113; 2011.

12. Andrade-Cetto A. Ethnobotanical study of the medicinal plants from Tlanchinol, Hidalgo, México. J. Ethnopharmacol. 2009; 122: 163-171.

13. Gonzalez AG, Aguiar ZE, Grillo TA, Luis JG, Rivera A, Calle J. Methoxy flavone from Ageratum conyzoides. Phytochemistry. 1991; 30: 1269-1271.

14. Achola K, Munenge RW, Mwaura AM. Pharmacological properties of root and aerial parts extracts of Ageratum conyzoides on isolated ileum and heart. Fitoterapia. 1994; 56: 103-109.

15. Khan MA, Pradhan D. Antiurolithic activity of Ageratum conyzoides extract in rats. Pharmacologyonline. 2011; 3: 953-958.

16. Amal MMN, Sami AK, Marcel K, Reto B, Wai EA, Thomas JS. The antiprotozoal activity methylated flavonoids from Ageratum conyzoides $L$. J. Ethnopharmacol. 2010; 129:127-130

17. Burkill HM. The Useful Plants of West Tropical Africa. Kew, UK: Royal Botanic Gardens (2 nd edition)Vol. 1, p. 1-960; 1985.

18. Shirwaikar A, Bhilegoankar PM, Malini S, Kumar JS. The gastroprotective activity of the ethanol extract of Ageratum conyzoides. J. Ethnopharmacol. 2003; 86(1): 117-121.

19. Rao JT, Nigam SSR. Ageratum conyzoides L. (Asteraceae). Aromen Koerperpfleg. 1973; 23: 209-212.

20. Ekundayo O, Laasko I, Hiltunen R. Essential Oil of Ageratum conyzoides. Plant Medicine. 1988; 519: 55-57.

21. Nair AGR, Kotiyal JP, Subramaian SS. Chemical constituents of the leaves of Ageratum conyzoides. Indian J. Pharmacol. 1977; 39: 108.

22. Adewole LO. Ageratum Conyzoides L. (Asteraceae). Fitoterapia. 2002; 73: 1-16.

23. Wiedenfeld $\mathrm{H}$, Roder E. Pyrrolizidine Alkaloids from Ageratum conyzoides Planta Med. 1991; 57: 578-579.

24. Pari K, Rao PJ, Subrahmaniam B, Rasthogi JN, Devakumar C. Benzofuran and other constituents of the essential oil Ageratum conyzoides. Phytochemistry. 1998; 199: 1385-1388.

25. Sarin R, Bansal N. Phytosterols from in-vivo and in-vito cultures of two medicinal plants Viz. Adhartoda vasica and Ageratum conyzoides. International Journal of Research in Ayurveda and Pharmacology. 2011; 2(3): 927-930.

26. Sharma GP, Garg BD, Girgune JB, Jain NK. Chemical investigation of the essential oil from Ageratum conyzoides Linn. Univ. Indore Res. 1980; 6: 6-11.

27. Quijano L, Calderson JS, Gomez GF, Rios T. Two polymethoxy flavones from Ageratum houstonianum. Phytochemistry. 1982; 21: 2965-2967.

28. Wandji J, Bissangou MF, Ouambra JM, SilouT, Abena A, Keita A. Allelochemicals from Ageratum conyzoides L. and Oryza sativa L.and their effects on related Pathogens. Fitoterapia. 1996; 67: 1927.

29. KatsuriTR, Manithomes TM. Essential oil of Ageratum conyzoides-isolation and structure of two new constituents. Tetrahedron Lett. 1967; 27: 2573.

30. Dubey S, Gupta KC, Matsumoto T. Sterols of Ageratum conyzoides L. Herba Hung. 1989; 28:71.

31. Iqbal MCM, Jayasinghe ULB, Herath HMTB, Wijesekara KB, Fujimoto YA fungistatic chromene from Ageratum conyzoides. Phytoparasitology. 2004; 32(2): 119-126.

32. Tyagi S, Sarrat S, Ojha AC. Chemical investigation of some medicinal plants of Shiwalik Hills, Asian J Chem. 1995; 7: 165-167

33. Yadava RN, Saurabh KS. A new isoflavone from the stems of Ageratum conyzoides. Fitoterapia. 1999; 70: 1975-1977 
34. Abena A, Kintsangoula-Mbaya GS, Diantama J, Bioka D. Analgesic effects of a raw extract of Ageratum conyzoides in the rat. Encephale. 1993; 19(4): 329-332.

35. Moura ACA, Silva ELF, Fraga MCA, Wanderley AG, Afiatpour P, Maia MBS. Antiinflammatory and chronic toxicity study of the leaves of Ageratum conyzoides in rats. Phytomedicine. 2005; 12(1-2): 138-192.

36. Rahman MA, Akter N, Rashid H, Ahmed NU, Uddin N, Islam M. S. Analgesic and anti-inflammatory effect of whole Ageratum conyzoides and Emilia sonchifolia alcoholic extracts in animal models. Afr. J. Pharm Pharmaco. 2012; 6(20): 1469-1476.

37. Shekhar TC, Anju G. Antioxidant Activity by DPPH Radical Scavenging Method of Ageratum conyzoides Linn. Leaves. American Journal of Ethnomedicine. 2014; 1 (4): 244-249.

38. Okemy-Andissa N, Ouamba JM, Koudou J, Diatewa M, Gleassor H, Abena AA. Comparative Study of Analgesic Activities of Tetra and an Association of Three Plants: Ageratum conyzoides, Combopogon citrates and Lippia multiflora. Int. J. Pharmacol. 2006; 2: 42.

39. Jose F. G, Magalhaes CFG, Viana AGM, Aragão VG, Moraes RA, Ribeiro MRV. Analgesic and anti-inflammatory activities of Ageratum conyzoides in rats. Phytother Res. 1997; 11(3): 183-188.

40. Tandon SK, Chandra S, Tripathi HC. Pharmacological effects of Ageratum conyzoides roots. Indian J. Pharm. Sci. 1994; 56: 182

41. Galati EM, Miceli N, Taviano MF, Sanogo R, Raneri E. Anti-inflammatory and antioxidant activity of Ageratum conyzoides. Pharm. Biol. 2001; 39(5): 336-339.

42. Mahmood AA, Sidik I, Salmah I, Suzainor KA, Philip K. Antiulcerogenic activity of Ageratum conyzoides leaf extract against ethanol-induced gastric ulcer in rats as Animal model. International Journal of Molecular Medicine and Advance Sciences. 2005; 1: 402-405.

43. Kamboj A, Saluja AK. Ageratum conyzoides L.: A review on its phytochemical and pharmacological profile. Int. J. Green Pharm. 2008; 2(2): 59-68.

44. Magalhaes JF, Viana CF, Aragao AG, Moraes VG, Ribeiro RA, Vale MR. Analgesic and anti-inflammatory activities of Ageratum conyzoides in rats. Phytother Res. 1997; $11: 183$.

45. Sampson JH, Phillipson JD, Bowery NG. Ethnomedicinally selected plants as sources of potential analgesic compounds; Indication of in vitro biological activity in receptor binding assays. Phytother Res. 2000; 119(1): 219-221.

46. Adebayo AH, Tan NH, Akindahunsi ZGZ, Zhang YM. Anticancer and antiradical scavenging activity of Ageratum conyzoides L. (Asteraceae) Pharmacogn. Mag. 2010; 6(21): 62-66

47. Odeleye OP, Oluyege JO, Aregbesola OA, Odeleye PO. Evaluation of preliminary phytochemical and antibacterial activity of Ageratum conyzoides $(\mathrm{L})$ on some clinical bacterial isolates. Int. J. Eng. Sci. 2014; 3(6):1-5

48. Mustafa MR, Mahmood AA, Sidik K, Noor SM. Evaluation of wound healing potential of Ageratum conyzoides leaf extract in combination with honey in rats as animal model. International Journal of Molecular Medicine and Advance Sciences. 2005; 1: 406-410.

49. Roland NN, Alertia EMT, Susan MM, Henry NL, Agnes M, Lucy MN, Kennedy N, Clare W, Simon MNE. In vitro anti-Helicobacter pylori activity of extracts of selected medicinal plants from North West Cameroon. J. Ethnopharmacol. 2007; 114(3), 452-457.

50. Neelabh C, Nahid A, Navneet K. Study on methanolic extract of Ageratum conyzoides for its ability to act as an antioxidant and to suppress the microbial growth. The Pharma Innovation Journal. 2017; 6(11): 170-173.

51. Chah KF, Eze CA, Emuelosi CE, Esimone CO. Antibacterial and wound healing properties of methanolic extracts of some Nigerian medicinal plants. J. Ethnopharmacol. 2006; 104 (1-2): 164-167.

52. Bayala B, Bassole IHN, Gnoula C, Nebie R, Yonli A, Morel L, Figueredo G, Nikiema JB, Lobaccaro JMA, Simpore J. Chemical Composition, Antioxidant, Anti-Inflammatory and Anti-Proliferative Activities of Essential Oils of Plants from Burkina Faso. PLOS ONE. 2014; 9(3): 1-11.

53. Whittle SR, Turner A. Antibacterial activities of Ageratum conyzoides. J. Biochem. Pharmacol. 1981; 30: 1191-1196.

54. Pattnaik S, Subramayam V, Perumal SR, Igancimuthu S, Patric R. D. Preliminary Screening of ethnomedicinal plants from India. J. Ethnopharmacol. 1999;66: 235-290.

55. Fiori ACG, Schwan -Estrada KRF, Stangarlin JR. Antifungal activities of leaf extracts and essential oils of some medicinal plants against Didimella bryoniae. J. Phytopathol. 2000; 148: 483-487.

56. Mishra DN, Dixit V, Mishra AK. Mycotoxic evaluation of some higher plants against ringworm causing fungi. Indian Drugs. 1991; 28: 300-303.

57. Moody JO, Adebiyi OA, Adeniyi BA. Do aloe vera and Ageratum conyzoides enhance the anti-microbial activity of traditional medicinal soft soaps (Osedudu). J. Ethnopharmacol. 2004; 92: 57-60.

58. Akinyemi KO, Oladapo O, Okwara CE, Ibe CC, Fasure K.A. Screening of crude extracts of six medicinal plants used in South- West Nigerian unorthodox medicine for antimethicillin resistant Staphylococcus aureus activity. BMC Complement. Altern. Med. 2005; 5: 6-8.
59. Almagboul AZ, Farrog AA, Tyagi BR. Antimicrobial activity of certain Sudanese plants used in folkloric medicine: Screening for antibacterial activity, Part-2. Fitoterapia. 1985; 56: 103-105.

60. Nweze NE, Obiwulu IS. Anticoccidial effects of Ageratum conyzoides. J. Ethnopharmacol. 2009; 122(1): 6-9.

61. de Melo NI, Magalhaes LG, de Carvalho CE, Wakabayashi KA, de P Aguiar G, Ramos RC, Mantovani AL, Turatti IC, Rodrigues V, Groppo M, Cunha WR, Veneziani RC, Crotti AE. Schistosomicidal activity of the essential oil of Ageratum conyzoides L. (Asteraceae) against adult Schistosoma mansoni worms. Molecules. 2011; 16 (1): 762-773.

62. Akah PA. Haemostatic activities of aqueous leaf extract of Ageratum conyzoides L. Int. J. Crude Drug Res. 1988; 26: 97-99.

63. Rosangkima G, Prasad SB. Antitumor activity of some plants from Meghalaya and Mizoram against Murine ascites Dalton's lymphoma. Indian J. Exp. Biol. 2001;192(10): 981-988.

64. Garcia EA. Carvalho MP. Electrophysiological effects of Ageratum conyzoides L. on guinea-pig heart. Phytother Res. 1999; 13: 172-174.

65. Gupta A Gupta RA survey of plants for presence of cholinesterase activity. Phytochemistry. 1997; 46: 827-831.

66. Lans C. Ethnomedicines used in Trinidad and Tobago for reproductive problems. J Ethnobiol Ethnomed. 2007; 3: 13.

67. Ita SO, Etim OE, Ben EE, Ekpo OF. Haematopoietic properties of ethanolic leaf extract of Ageratum conyzoides (goat weed) in albino rats. Niger. J. Physiol. Sci. 2007;22(1-2): 83-87.

68. Preeti S, Lalit M, Chand NS. Anti-juvenile activity of Azadirachta indica extract on the development and morphometry of filaria vector, Culex quinquefasciatus (Diptera:Culicidae) Say. Parasitol Res. 2009; 105: 1193--1203.

69. Sahoo M, Chand PK. In vitro multiplication of a medicinal herb Tridax procumbens L. (Mexican Daisy, coat button): influence of explanting season, growth regulator synergy, culture passage and planting substrate. Phytomorphology. 1998; 48:195-206.

70. Khan SK, Rahman AHMM, Alam MS, Ahmed F, Rafiul IAKM, Rahman MM.Taxonomic studies on the family Asteraceae (Compositae) of the Rajshahi Division. Res J. Agric. \& Biol. Sci. 2008; 4(2): 134-140.

71. Bhagwat DA, Killedar SG, Adnaik RS. Anti-diabetic activity of leaf extract of Tridax procumbens. Int. J. Green Pharm. 2008;2(2): 126-128.

72. Ali M, Ravinder E, Ramachandram R. Phytochemical communication a new flavonoid from the aerial parts of Tridax procumbens. Fitoterapia. 2001 ; 72 : 313315.

73. Pathak AK, Saraf S, Dixit VK. Hepatoprotective activity of Tridax procumbens Part I. Fitoterapia. 1991; 62: 307-313.

74. Saraf S, Pathak AK, Dixit VK. Hair growth promoting activity of Tridax procumbens. Fitoterapia. 1991; 62: 495-498.

75. Ravikumar V, Shivashangari K, Devaki T. Effect of Tridax procumbens on liver antioxidant defence system during lipopolysaccharide-induced hepatitis in D-galactosamine sensitised rats. Mol Cell Biochem. 2005; 269: 131-136.

76. Vishnu PP, Radhika K, Sivakumar R, Sri Ramchandra M, Prameela DV, Rao S Evaluation of Anti-Cancer Activity of T. Procumbens Flower Extracts on PC3 cell lines. An International Journal of Advances in Pharmaceutical Sciences. 2011; 2(1): 28-30.

77. Saini A, Soni HK Gupta PA. Review on Tridax procumbens. Imperial Journal of Interdisciplinary Research (IJIR). 2016; 2 (8), 308-319

78. Singh K, Ahirwar V. Acute and chronic toxicity study of Tridax procumbens on haemoglobin percent and blood sugar level of Sprague Dawley rats. J. Pharmacol Toxicol. 2010; 1(1): 1-6.

79. Rajbala. A study on Ayurvedic herb Tridax procumbens plant (Asteraceae) International Journal of Advance Research in Science and Engineering (IJARSE) 2014; 3(12):406-409.

80. Pande PS, Mishra MN. Isolation and identification of quercetin and rutin from leaves of Tridax procumbens Linn by HPLC analysis. International Journal of Chemical and Physical Sciences. 2015; 4: 65-68.

81. Runsheg $X$, Zhang J, Yuan K. Two flavones from Tridax procumbens Linn. Molecules. 2010; 15: 6357-6364.

82. Ali MS, Jahangir MA. Bis-bithiophene from Tridax procumbens L. (Asteraceae) Nat Prod Lett. 2002; 16(4): 217-221.

83. Ikewunchi JC, Ikewunchi CC, Ngozigboh MI. Chemical profile of Tridax procumbens Linn, Pakistan J Nutr. 2009; 8(5): 548-550.

84. Wen-Hao C, Xing-Ming M, Quan-Xiang W, Yan-Ping S. Chemical constituent diversity of Tridax procumbens. Can. J. Chem. 2008; 86(9): 892-898.

85. Ali MS, Jahangir M, Hussain S, Choudhary M. Inhibition of a-glucosidase by oleanolic acid and its synthetic derivatives. Phytochemistry. 2002; 60: 295-299.

86. Verma RK, Gupta MM. Lipid constituents of Tridax procumbens. Phytochemistry 1998; 27(2): 459-463. 
87. RajuTS, Davidson EA. Structural Features of water-soluble novel polysaccharide components from the leaves of Tridax procumbens Linn. Carbohydr. Res. 1994; 258: 243-254.

88. Bhat RS, Shankrappa J, Shivakumar HG. Formulation and evaluation of polyherbal wound treatments. Asian J. Pharm. Sci. 2007;2(1): 11--17.

89. Agrawal S, Mohale D, Talele GS. Pharmacological activities of Tridax procumbens (Asteraceae). Med. Plants. 2010; 2(2), 73-78.

90. Udupa SL, Udupa AL, Kulkarni DR. Influence of Tridax procumbens on dead space wound healing. Fitoterapia. 1991, 62(2): 146-150.

91. Nia R, Paper DH, Essien EE, Oladimeji OH, Iyadi KC, Franz G. Investigation into in-vitro radical scavenging and in-vivo anti-inflammatory potential of Tridax procumbens. Niger. J. Physiol. Sci. 2003; 18(1-2); 39-43.

92. Vilwanthan R, Shivshangari KS, Devak T. Hepatoprotective activity of Tridax procumbens against dgalactosamine/ lipopolysaccharide-induced hepatitis in rats. J. Ethnopharmacol. 2005; 101: 55-60.

93. Salahdeen HM, Yemitan OK, Alada ARA. Effect of aqueous leaf extract of Tridax procumbens on blood pressure and heart rate in rats. Afr J Biomed Res. 2004; 7: $27-29$.

94. Oladunmoye MK. Comparative Evaluation of Antimicrobial Activities and Phytochemical Screening of Two Varieties of Acalypha wilkesiana. Trends Appl. Sci. Res. 2006; 1:538-541.

95. Tiwari U, Rastogi B, Singh P, Saraf DK, Vyas SP. Immunomodulatory effects of aqueous extract of Tridax procumbens in experimental animals. J. Ethanopharmacol. 2004; 92: 113-119.

96. Perumal SR, Ignacimuthu S, Patric RD. Preliminary screening of ethnomedicinal plants from India. J. Ethnopharmacol. 1999; 66(2), 235-240.

97. Pai C, Kulkarni U, Borde M, Murali S, Mrudula P, Deshmukh Y. Antibacterial activity of Tridax procumbens with special reference to Nosocomial pathogens. Br J Pharm Res. 2011; 1: 164-173.

98. Mahato RB, Chaudhary RP. Ethnomedicinal study and bacterial activities of selected plants of Palpa district, Nepal. Sci World J. 2005; 3(3): 26-31.

99. Alcaraz MJ, Jimenez MJ. Flavonoids as anti-inflammatory agents. Fitoterapia. 1988;59 (1): 25-38.

100. Karis PO, Ryding O. Asteraceae Cladistics and Classification, Bremer K. Editors. Asteraceae : cladistics \& classification. Portland, USA: Timber press, p. 559-569; 1994

101. Pozharitskava ON, Shikov AN, Makarova MN, Kosman VM, Faustova NM, Tesakova SV, Makarov VG, Galambosi B. Anti-inflammatory activity of a HPLC-fingerprinted aqueous infusion of aerial part of Bidens tripartita L. Phytomedicine. 2010; 17 (6): 463-468.

102. Bartolome AP, Villaseñor IM, Yang WC. Review Article Bidens pilosa L. (Asteraceae): Botanical properties, traditional uses, phytochemistry, and pharmacology. Evid. Based Complementary Altern. Med. 2013: 1-51.

103. Palmer C. Platago spp. and Bidens spp: A case study of change in Hawaiian Herbal medicine. J. Ethnobiol. 2004; 24(1): 13-31.

104. Pereira RLC, Ibrahim T, Lucchetti L, Da Silva AJR, De Moraes VLG. Immunosuppressive and anti-inflammatory effects of methanolic extract and the polyacetylene isolated from Bidens pilosa L. Immunopharmacology. 1999; 43 (1): 31-37.

105. Tan PV, Dimo T, Dongo E. Effects of methanol, cyclohexane and methylene chloride extracts of Bidens pilosa on various gastric ulcer models in rats. J. Ethnopharmacol. 2000;73(3): 415-421.

106. Dimo T, Azay J, Tan PV, Pellecuer J, Cros G, Bopelet M, Serrano JJ. Effects of the aqueous and methylene chloride extracts of Bidens pilosa leaf on fructose hypertensive rats. J. Ethnopharmacol. 2001; 76 (3): 215-221.

107. Falowo DE, Oladunmoye MK. Antibacterial activity of Bidens pilosa extracts on Escherichia coli 0157: $\mathrm{H} 7$ isolated from apparently healthy individuals. Asian Journal of Medicine and Health. 2018; 11(2): 1-10.

108. Redl K, Breu W, Davis B, Bauer R. Anti-inflammatory active polyacetylenes from Bidens campylotheca, Planta Med. 1994; 60 (1): 58-62.

109. Silva FL, Fischer DCH, Tavares JF, Silva MS, De Athayde-Filho PF, BarbosaFilho JM. Compilation of secondary metabolites from Bidens pilosa L, Molecules. 2011; 16(2): 1070-1102.

110. Yang WC. Review article Botanical, pharmacological, phytochemical, and toxicological aspects of the antidiabetic plant Bidens pilosa L. Evid-Based Complementary Altern. Med. 2014: 1-14.

111. Chien SC, Young PH, Hsu YJ, Tien YJ, Shiu SY, LiTH, Yang CH, Marimuthu $P$, Tsai LFL, Yang WC. Anti-diabetic properties of three common Bidens pilosa variants in Taiwan, Phytochemistry. 2009; 70(10): 1246-1254.

112. Chang SL, Chiang YM, Chang CLT,Yeh HH, Shyur LF, Kuo YH, WuTK Yang WC. Flavonoids, centaurein and centaureidin, from Bidens pilosa, stimulate IFN- $\gamma$ expression. J. Ethnopharmacol. 2007; 112(2):232-236

113. Chang M, Wang G, Kuo YH, Lee CK. The low polar constituents from Bidens pilosa L. var. minor (Blume) Sheriff. J Chin Chem Soc. 2000; 47: 1131-1136.
114. Lee TH, Lu CK, Kuo YH, Lo JM, Le CK. Unexpected novel pheophytin peroxides from the leaves of Bidens pilosa. Helv. Chim. Acta. 2008; 91:79-84.

115. Khanh TD, Cong LC, Xuan TD, Uezato Y, Deba F, Toyama T, Tawata S Allelopathic plants: 20. Hairy beggarticks (Bidens pilosa L.). Allelopathy J. 2009; 24: 243-254.

116. Chiang YM, Chuang DY, Wang SY, Kuo YH, Tsai PW, Shyur LF. Metabolite profiling and chemo preventive bioactivity of plant extracts from Bidens pilosa. J. Ethnopharmacol. 2004; 95 (2-3): 409-419.

117. Deba F, Xuan TD, Yasuda M, Tawata S. Herbicidal and fungicidal activities and identification of potential phytotoxins from Bidens pilosa L. var. radiata Scherff: research paper. Weed Biol. Manag. 2007; 7(2): 77-83.

118. Deba F, Xuan TD, Yasuda M, Tawata S. Chemical composition and antioxidant, antibacterial and antifungal activities of the essential oils from Bidens pilosa Linn. var. Radiata. Food Control. 2008; 19(4): 346-352.

119. Xuan TD, Khanh TD. Chemistry and pharmacology of Bidens pilosa: an overview. J. Pharm. Investig. 2016; 46(2): 91-132.

120. Sashida Y, Ogawa K, Kitada M, Karikome H, Mimaki Y, Shimomura H. New aurone glucosides and new phenylpropanoid glucosides from Bidens pilosa. Chem. Pharm. Bull. 1991; 39: 709-711.

121. Wang J, Yang H, Lin ZW, Sun HD. Flavonoids from Bidens pilosa var. radiata Phytochemistry. 1997; 46: 1275-1278.

122. Lee WJ, Wu LF, Chen WK, Wang CJ, Tseng TH. Inhibitory effect of luteolin on hepatocyte growth factor/ scatter factor-induced HepG2 cell invasion involving both MAPK/ERKs and PI3K-Akt pathways. Chem-Biol Interact. 2006;160(2): 123-133

123. Kumari P, Misra K, Sisodia BS, Faridi U, Srivastava S, Luqman S, Darokar MP, Negi AS, Gupta MM, Singh SC, Kumar JKA. Promising anticancer and antimalarial component from leaves of Bidens pilosa. Planta Med. 2009;75: 59-61.

124. Yit C. C, Das NP. Cytotoxic effect of butein on human colon adenocarcinoma cell proliferation. Cancer Lett. 1994; 82(1): 65-72.

125. Beutler JA, Hamel E, Vlietinck AJ, Haemers A, Rajan P, Roitman JN, Cardellina $\mathrm{JH}$, Boyd MR. Structure-activity requirements for flavone cytotoxicity and binding to tubulin, J. Med. Chem. 1998; 41(13): 2333-2338.

126. Wu LW, Chiang YM, Chuang HC, Wang S. Y, Yang G.W, Chen, YH, Lai LY, Shyur LF. Polyacetylenes function as anti-angiogenic agents. Pharm. Res. 2004; 21: 2112-2119.

127. Kviecinski MR, Felipe KB, Schoenfelder, $T$, de Lemos Wiese LP, Rossi M $\mathrm{H}$, Gonçalez E, Felicio JD, Filho DW, Pedrosa RC. Study of the antitumor potential of Bidens pilosa (Asteraceae) used in Brazilian folk medicine. J. Ethnopharmacol. 2008; 117(1): 69-75.

128. Yoshida N, Kanekura T, Higashi Y, Kanzaki T. Bidens pilosa suppresses interleukin- $\beta$-induced cyclooxygenase- 2 expression through the inhibition of mitogen activated protein kinases phosphorylation in normal human dermal fibroblasts. J. Dermatol. 2006; 33 (10): 676-683.

129. Horiuchi M, Seyama Y. Improvement of the anti-inflammatory and antiallergic activity of Bidens pilosa L. var. radiata SCHERFF treated with enzyme (Cellulosine). J. Health Sci. 2008; 54(3): 294-301.

130. Ubillas RP, Mendez CD, Jolad SD, Luo J, King SR, Carlson TJ, Fort DM. Antihyperglycemic acetylenic glucosides from Bidens pilosa. Planta Med. 2000; 66(1): 82-83.

131. Lin HW, Han GY, Liao SX. Studies on the active constituents of the Chinese traditional medicine Polygonatum odoratum (Mill) Druce. Acta Pharmaceutica Sinica. 1994; 29 (3): 215-222.

132. Connelly P. Horrible weed or miracle herb? A review of Bidens pilosa. J Aust Tradit-Med So. 2009; 15: 77-79

133. Chang SL, Chang CLT, Chiang YM, Hsieh RH, Tzeng CR, Wu TK, Sytwu H $\mathrm{K}$, Shyur LF, Yang, WC. Polyacetylenic compounds and butanol fraction from Bidens pilosa can modulate the differentiation of helper T cells and prevent autoimmune diabetes in non-obese diabetic mice. Planta Med. 2004; 70(11); 1045-1051

134. Dey L, Attele AS, Yuan CS. Alternative therapies for type 2 diabetes. Altern Med Rev. 2002;7(1): 45-58.

135. Chang CLT, Chang SL, Lee YM, Chiang YM, Chuang DY, Kuo HK, Yang WC. Cytopiloyne, a polyacetylenic glucoside, prevents type 1 diabetes in nonobese diabetic mice. J. Immunol. 2007; 178(11): 6984-6993.

136. Chang CLT, Liu HY, Kuo TF, Hsu YJ, Shen MY, Pan CY, Yang WC. Anti-diabetic effect and mode of action of cytopiloyne. Evid-Based Complementary Altern Med. 2013: 1-13.

137. Hsu YJ, Lee TH, Chang CLT, Huang YT, Yang WC. Anti-hyperglycaemic effects and mechanism of Bidens pilosa water extract, J. Ethnopharmacol. 2009; 122(2): 379-383. 
138. Muchuweti M, Mupure C, Ndhlala A, Murenje T, Benhura MAN. Screening of antioxidant and radical scavenging activity of Vigna ungiculata, Bidens pilosa and Cleome gynandra. Am. J. Food Technol. 2007; 2(3):161-168.

139. Chang CLT, Kuo HK, Chang SL, Chiang YM, Lee TH, Wu WM, Shyur LF, Yang WC. The distinct effects of a butanol fraction of Bidens pilosa plant extract on the development of Th1-mediated diabetes and Th2-mediated airway inflammation in mice. J. Biomed. Sci. 2005; 12(1): 79-89.

140. Brandao MGL, Krettli A, Soares L, Nery CG, Marinuzi HC. Antimalaria activity of extracts and fractions from Bidens pilosa and other Bidens species (Asteraceae) correlated with the presence of acetylene and flavonoid compounds. J. Ethnopharmacol. 1997; 57: 131-138.

141. Andrade-Neto VF, Brandao MG, Oliveira FQ, Casali VW, Njaine B, Zalis M G, Oliveira LA, Krettli AU. Antimalarial activity of Bidens pilosa L. (Asteraceae) ethanol extracts from wild plants collected in various localities or plants cultivated in humus soil. Phytother Res. 2004; 18: 634-639.

142. Oliveira FQ, Andrade-Neto $V$, Krettli AU, Brandao MGL. New evidences of antimalarial activity of Bidens pilosa roots extracts correlated with polyacetylene and flavonoids. J. Ethnopharmacol. 2004; 93: 39-42.

143. N'Douga M, Balansard G, Babadjamian A, David PT, Gasquet M. Studies on Bidens pilosa L. Identification and antiparasitic activity of 1-phenyl-1,3,5heptatriyne. Plant Med Phytother. 1983; 17: 64-75.
144. Tobinaga S, Sharma MK, Aalbersberg WGL, Watanabe K, Iguchi K, Narui K, Sadatsu M, Waki S. Isolation and identification of a potent antimalarial and antibacterial polyacetylene from Bidens pilosa. Planta Med. 2009; 75: 624-628.

145. Uchoa VT, Paula RC, Krettli LG, Stantana AEG, Krettli AU. Antimalarial activity of compounds and mixed fractions of Cecropia pachystachya. Drug Dev. Res. 2010; 71: 82-91.

146. Brandao MGL, Nery CGC, Mamao MAS, Krettli AU. Two methoxylated flavones aglycosides from Bidens pilosa. Phytochemistry. 1998; 48: 397-399.

147. Chang SL, Yeh HH, Lin YS, Chiang YM, Wu TK, Yang WC. The effect of centaurein on interferon- $\gamma$ expression and Listeria infection in mice, Toxicol Appl Pharm. 2007; 219(1):54-61

148. Ashafa AOT, Afolayan AJ. Screening the root extracts from Biden pilosa L. var. radiata (Asteraceae) for antimicrobial potentials. J. Med. Plant Res. 2009; 3(8): 568-572.

149. Dimo T, Nguelefack TB, Tan PV, Yewah MP, Dongo E, Rakotonirina SV, Kamany A, Bopelet M. Possible mechanisms of action of the neutral extract from Bidens pilosa $\mathrm{L}$. leaves on the cardiovascular system of anaesthetized rats. Phytother Res. 2003; 17(10): 1135-1139.

150. Hassan AK, Deogratius O, Nyafuono J. F, Francis O, Engeu OP. Wound healing potential of the ethanolic extracts of Bidens pilosa and Ocimum suave. Afr J Pharm Pharmacol. 2011;5(2):132-6. 


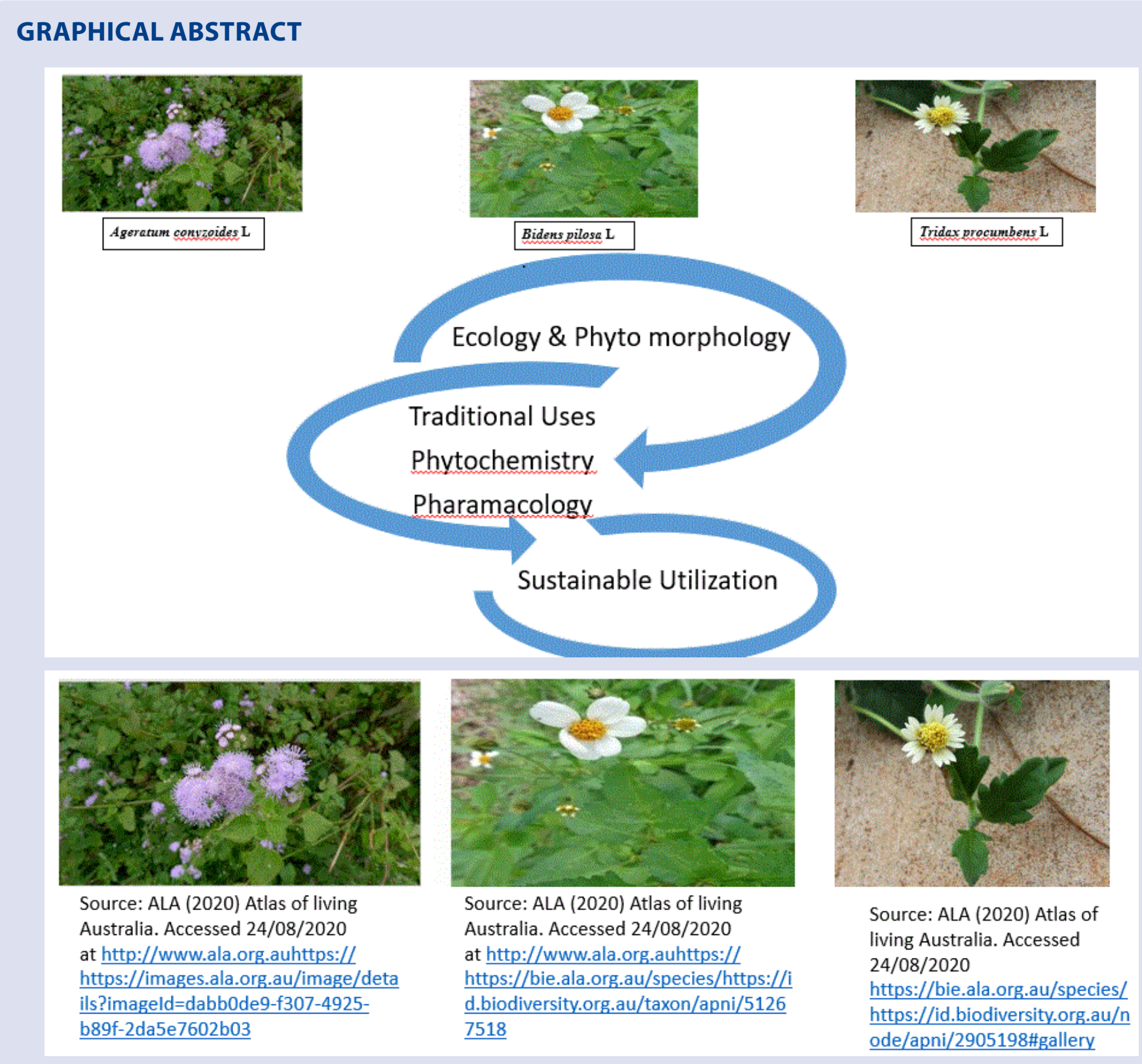

\section{ABOUT AUTHORS}

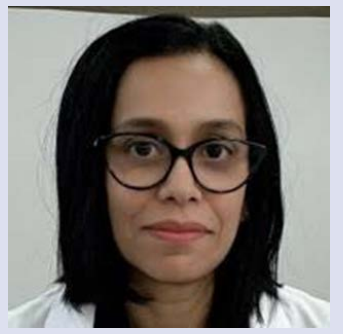

\section{Mithila Jayasundera}

Mithila has been a casual academic in Food Science and Technology at the School of Science, RMIT University, Melbourne, Australia since 2015. She received her Ph.D. degree in Food Science and Technology from the Federation University, Australia in 2011. She has participated sufficiently in writing of the manuscript on Medicinal Value of Three 


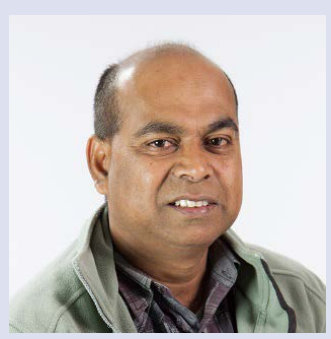

Singarayer Florentine is a restoration and invasive species ecologist. Florentine established a powerful University-centred Invasive species and restoration research group informed by a strategic programmatic research platform based upon understandings of complex and urgent ecological restoration issues. Florentine led the development of strong collaborative research partnerships with over 20 natural-resource management groups here in Australia. Florentine published over 100 research papers, and supervised several PhD, MSc and Honours students.

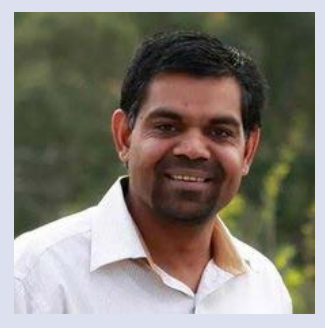

Bhagirath Chauhan leads an applied Weed Science and Management Program at the Queensland Alliance for Agriculture and Food Innovation (QAAFI) and School of Agriculture and Food Sciences (SAFS), The University of Queensland, Gatton, Australia. The major theme of his work is to develop sustainable and effective integrated weed management tactics for different cropping systems in Australia and other countries. His research interests are weed biology, seed ecology, herbicide resistance, climate change and integrated weed management.

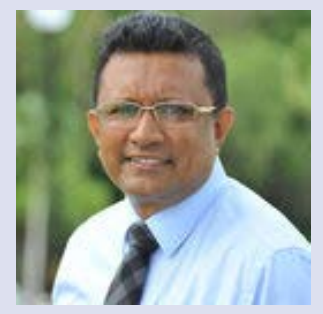

Kushan Tennakoon is a plant eco-physiologist with research experience in South East Asia, USA and Australia. Currently he is attached to Federation University, Berwick Campus, Melbourne Australia. His research is focused on plant responses to environmental change, biology of native plants and developing propagation and agronomic practices of selected medicinal plants. Kushan has received numerous professional awards including the Fulbright Senior Fellowship (USA) and the Third World Academy of Sciences (TWAS) Young Scientist Award for Biology.

Cite this article: Jayasundera M, Florentine S, Tennakoon KU, Chauhan BS. Medicinal Value of Three Agricultural Weed Species of the Asteraceae Family: A Review. Pharmacog J. 2021;13(1): 264-77. 